\title{
Spatial and temporal variations in Greenland glacial-earthquake activity, 1993-2010
}

\author{
Stephen A. Veitch ${ }^{1}$ and Meredith Nettles ${ }^{1}$ \\ Received 13 March 2012; revised 6 July 2012; accepted 23 August 2012; published 9 October 2012.
}

[1] Glacial earthquakes are anomalous earthquakes associated with large ice-loss events occurring at marine-terminating glaciers, primarily in Greenland. They are detectable teleseismically, and a proper understanding of the source mechanism may provide a remote-sensing tool to complement glaciological observations of these large outlet glaciers. We model teleseismic surface-wave waveforms to obtain locations and centroid-singleforce source parameters for 121 glacial earthquakes occurring in Greenland during the period 2006-2010. We combine these results with those obtained by previous workers to analyze spatial and temporal trends in glacial-earthquake occurrence over the 18-year period from 1993-2010. We also examine earthquake occurrence at six individual glaciers, comparing the earthquake record to independently obtained observations of glacier change. Our findings confirm the inference that glacial-earthquake seismogenesis occurs through the capsize of large, newly calved icebergs. We find a close correspondence between episodes of glacier retreat, thinning, and acceleration and the timing of glacial earthquakes, and document the northward progression of glacial earthquakes on Greenland's west coast over the 18-year observing period. Our results also show that glacial earthquakes occur when the termini of the source glaciers are very close to the glacier grounding line, i.e., when the glaciers are grounded or nearly grounded.

Citation: Veitch, S. A., and M. Nettles (2012), Spatial and temporal variations in Greenland glacial-earthquake activity, 1993-2010, J. Geophys. Res., 117, F04007, doi:10.1029/2012JF002412.

\section{Introduction}

[2] Rapid changes in the Greenland Ice Sheet have been documented using a variety of methods over the last decade. Greenland's outlet glaciers have shown large-scale calvingfront retreat [e.g., Joughin et al., 2004; Howat et al., 2005; Luckman et al., 2006; Moon and Joughin, 2008], trunk acceleration [e.g., Joughin et al., 2004; Howat et al., 2005; Rignot and Kanagaratnam, 2006; Joughin et al., 2010], and thinning [e.g., Thomas et al., 2000; Abdalati et al., 2001; Krabill et al., 2004; Howat et al., 2005; Stearns and Hamilton, 2007]. Offshore, changes in ocean temperature [e.g., Holland et al., 2008; Howat et al., 2008; Murray et al., 2010; Straneo et al., 2010; Seale et al., 2011], both at the sea surface and at depth, have been observed, and appear to be linked to changes in the ice sheet, primarily through modulation of calving and melt rates at marine-terminating outlet glaciers. These changes coincide with the acceleration of mass loss in Greenland [e.g., Velicogna and Wahr, 2005; Luthcke et al., 2006; Rignot et al., 2008; Khan et al., 2010]. Variations in ice discharge at outlet glaciers contribute

\footnotetext{
${ }^{1}$ Department of Earth and Environmental Sciences and Lamont-Doherty Earth Observatory, Columbia University, Palisades, New York, USA.

Corresponding author: S. A. Veitch, Lamont-Doherty Earth Observatory, 61 Route 9W, Palisades, NY 10964, USA. (veitch@1deo.columbia.edu)

(C)2012. American Geophysical Union. All Rights Reserved. 0148-0227/12/2012JF002412
}

significantly to changes in Greenland's mass budget [Rignot et al., 2008], and account for roughly half of the total recent mass loss [van den Broeke et al., 2009]. However, the nature of the interaction between processes driving mass loss, including controls on glacier calving and retreat, remains poorly understood.

[3] Glacial earthquakes are globally observable seismic signals associated with large outlet glaciers. Glacial earthquakes were first identified by Ekström et al. [2003] through examination of long-period surface waves. They are located primarily along the coast of Greenland [Ekström et al., 2003], though a few events have also been detected in Antarctica [Ekström et al., 2003; Nettles and Ekström, 2010; Chen et al., 2011]. The earthquakes have magnitudes $\mathrm{M}_{S W}$ 4.6-5.2, and source durations that are very long (30-60 s) compared with tectonic earthquakes of similar size $(\sim 2 \mathrm{~s})$. The long source durations of these earthquakes, and resultant depletion in high-frequency energy, explains the absence of the glacial earthquakes from standard catalogs of global seismicity, which are based on high-frequency detections. The location of the events in tectonically inactive Greenland and the tight clustering of the earthquakes at large outlet glaciers [Ekström et al., 2006; Tsai and Ekström, 2007] suggest an association with glacier motion rather than tectonic activity. Additionally, seismograms from glacial earthquakes are poorly explained by moment-tensor source models appropriate for elastic faulting [Ekström et al., 2003; Tsai and Ekström, 2007], but are well explained by a single-force model like 
that previously used to model seismic emissions from large landslides [e.g., Kawakatsu, 1989]. Ekström et al. [2006] studied glacial earthquakes in Greenland from 1993-2005, and observed a seasonal pattern in which glacial earthquakes were most frequent in late summer. They also observed an increase in the frequency of earthquake occurrence between 2000 and 2005. Tsai and Ekström [2007] conducted a systematic analysis of 184 earthquakes occurring over 13 years (1993-2005) in Greenland. They demonstrated that the long source duration and "landslide" character of the events were consistent throughout the data set. They also found that the forces active at the earthquake source were predominantly aligned parallel or anti-parallel to glacier flow. Like previous authors [Ekström et al., 2003, 2006], Tsai and Ekström [2007] hypothesized that the seismicity resulted from sudden acceleration of a large ice mass at the source glaciers.

[4] The available data did not allow independent determination of the size of the accelerating mass and the distance over which it accelerated, and glacial earthquakes were initially believed to result from sudden sliding of large $\left(\sim 10 \mathrm{~km}^{3}\right)$ portions of the glacier trunk over distances of 1-10 m [Ekström et al., 2003, 2006]. A similar phenomenon has since been observed in association with smaller earthquakes at Whillans Ice Stream in Antarctica [Wiens et al., 2008], but recent studies of individual glaciers have now shown that this mechanism is likely not the cause of the glacial earthquakes observed in Greenland [e.g., Joughin et al., 2008a; Nettles et al., 2008a; Amundson et al., 2008; Nettles and Ekström, 2010]. These studies showed that glacial earthquakes are temporally associated with large calving events at the source glaciers, and that no stick-slip sliding of the glacier occurs during the earthquakes. Rather, glacial earthquakes are now understood to result from the capsizing of newly calved icebergs of cubic-km scale, which transfer momentum to the solid earth as their centers of mass accelerate away from the calving front over a distance of $100 \mathrm{~m}$ or more. These icebergs typically represent calving through the entire thickness of the glacier, with an along-flow extent of a few hundred meters and a cross-flow extent of several kilometers. Previous authors [Amundson et al., 2008; Nettles et al., 2008a; Nettles and Ekström, 2010] have also shown that glacier behavior during glacial earthquakes is consistent with seismogenesis at the calving front, and Tsai et al. [2008] demonstrated that such a mechanism is physically feasible. In addition, variations in the frequency of earthquake occurrence have been linked to variations in the rate of calvingfront retreat on both seasonal [Joughin et al., 2008a] and multiyear timescales [Nettles and Ekström, 2010].

[5] Much remains unknown about glacial earthquakes, and no systematic study of the earthquakes occurring in Greenland has been undertaken for events after 2005, or in light of the recently developed understanding of the connection between glacial earthquakes and calving processes. Although it has been suggested [Joughin et al., 2008a; Nettles and Ekström, 2010] that glacial earthquakes only occur when the calving front is grounded or near grounded, this hypothesis has been based on very limited data, and controls on the occurrence of glacial earthquakes are not well understood. Similarly, the relationship of the earthquakes to other observable changes in the Greenland Ice Sheet has only been documented in a few cases. The glacial-earthquake data set is limited, with source-parameter solutions currently available only for the period 1993-2005, for the 184 earthquakes studied by Tsai and Ekström [2007]. In contrast, the Global CMT project [Ekström et al., 2012] typically publishes $\sim 150$ focal-mechanism solutions for tectonic earthquakes each month. An expanded catalog of glacial earthquakes would offer greater insight into their occurrence and their link to ice dynamics, and increase the utility of glacial earthquakes as a tool for remote monitoring of the Greenland Ice Sheet.

[6] In this study, we model waveforms for 121 glacial earthquakes occurring in Greenland from 2006-2010 to obtain centroid-single-force source parameters and improved locations, in a manner consistent with the approach of Tsai and Ekström [2007]. This allows us to expand the record of well-documented and characterized glacial earthquakes by $65 \%$. We use these results together with the previously published event solutions of Tsai and Ekström [2007] to evaluate the extent to which the full glacial-earthquake data set is consistent with the iceberg-capsize model of glacialearthquake seismogenesis. We address controls on glacialearthquake occurrence, including the grounding state of the calving front. Finally, we examine regional and local trends in the occurrence and location of glacial earthquakes in Greenland in the context of ongoing changes in the Greenland Ice Sheet.

\section{Data and Methods}

\subsection{Event Detection}

[7] Because glacial earthquakes have unusually long source durations, the seismograms they generate are depleted in high-frequency energy and lack globally detectable shortperiod body waves [Ekström et al., 2003]. Teleseismic earthquake monitoring normally relies on the identification of short-period body waves, and glacial earthquakes are not identified by standard earthquake-detection algorithms. However, glacial earthquakes can be detected using surface waves in the manner described by Ekström et al. [2003] and Ekström [2006].

[8] Intermediate-period (35-150 s) Rayleigh waves recorded at stations of the Global Seismographic Network (GSN) are back-projected to possible earthquake source locations on a global grid of $4^{\circ} \times 4^{\circ}$ spacing by deconvolution of a surface-wave propagation operator. Envelope functions for each record are calculated, and detections are identified using a matched-filter approach. Grid points at which a sufficient number of records indicate the presence of an event are identified as potential earthquake detections. The grid is then further refined, eventually giving a resolution of $0.5^{\circ}$ for epicenter locations. The long wavelength of the surface waves used (e.g., $\sim 200 \mathrm{~km}$ for a $50 \mathrm{~s}$ Rayleigh wave) and the lack of phase information in the envelope functions result in location uncertainties for these detections that are relatively large $(50-80 \mathrm{~km})$.

[9] The surface-wave detection algorithm of Ekström [2006] has now been applied to broadband seismic records from the Global Seismographic Network for the period 2006-2010. We use the resulting catalog of event detections (Figure 1 and Table 1) to provide initial event locations and times for our waveform analysis. For events in 2006-2008, we adopt the published catalog of Nettles and Ekström [2010]. The data processing approach used in that study 


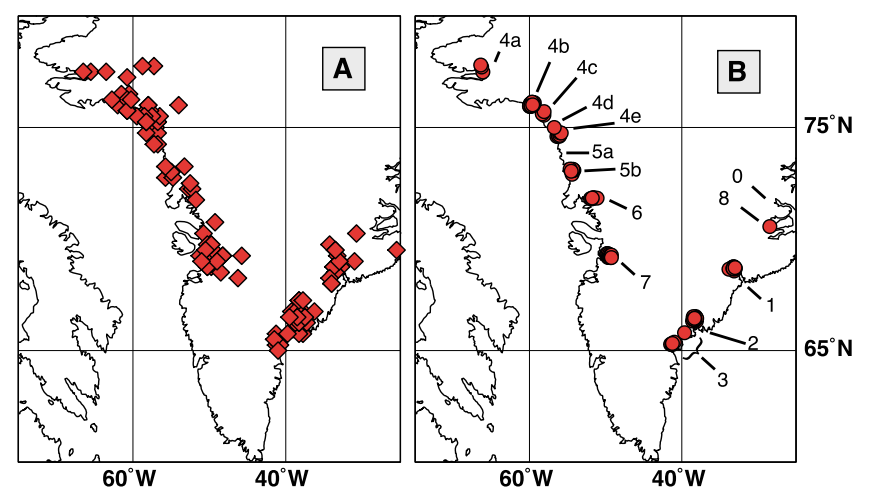

Figure 1. Locations of 121 glacial earthquakes, 2006-2010. (a) Locations of all events as determined by surface-wave detection. (b) Locations of the same events as determined by waveform inversion. Glaciers are labeled as in Table 1: 0: Daugaard-Jensen Glacier; 1: Kangerdlugssuaq Glacier; 2: Helheim Glacier; 3: Southeast Greenland (multiple glaciers); 4a: Tracy Glacier; 4b: Kong Oscar Glacier; 4c: Sverdrup Glacier; 4d: Hayes Glacier; 4e: Alison Glacier; 5a: Giesecke Bræer; 5b: Upernavik Isstrøm; 6: Rinks Glacier; 7: Jakobshavn Isbræ; 8: Rolige Bræ. While included on this figure for completeness, we note that neither Region 0 nor Region 5a produced glacial earthquakes during the period 2006-2010.

was designed for consistency with the previously published results of Ekström et al. [2006]; data for 2009-2010 have been processed in the same way. This consistency allows for direct comparison of event numbers between years, and we refer to events identified in this way as 'standard' detections. For 2009-2010, we also attempt waveform analyses for events identified by a version of the detection algorithm operating in near-real time and using a data set including a number of additional seismometers in or near Greenland. This results in the identification of several additional events, which we refer to as 'NRT' detections. Additionally, we include two standard detections from 2009 that are of lower quality than those considered in previous studies. The full data set thus provides times and initial locations for a total of 121 events in Greenland during 2006-2010: 111 standard detections (109 of them high-quality detections) and 10 NRT detections. We present waveform-modeling solutions for all events, but in our analyses of spatiotemporal variations we consider only the standard, high-quality detections in order to maintain consistency with previously published data from earlier years. For all events, we use the detection locations (shown in Figure 1a) and times as inputs for waveform modeling to determine centroid-single-force parameters, including improved locations.

\subsection{Waveform Inversion}

[10] We use a centroid-single-force (CSF) approach to invert seismic waveforms for earthquake source characteristics, including more accurate event locations. This process allows for the inclusion of phase information and manual removal of noisy or bad records. Previous studies [Ekström et al., 2003; Tsai and Ekström, 2007] have shown that waveform inversion using a centroid-moment-tensor (CMT) approach [Dziewonski et al., 1981], appropriate for elastic faulting, leads to solutions with a poor fit to the data, while inversions using a momentum transfer or "landslide" model of source physics and the CSF approach [Kawakatsu, 1989] reproduce the observed waveforms well. The model parameters determined using the CSF approach are the earthquake centroid location and depth, a time shift of the source centroid from the original detection time, and a three-dimensional vector describing the active force. The CSF amplitude $\mathrm{M}_{C S F}$, a product of mass and distance, is derived by twice integrating the force-time history [Kawakatsu, 1989], and is a quantity analogous to the seismic scalar moment. A standard CMT model provides centroid location and depth, time shift, and the six components of the moment tensor, from which the seismic scalar moment is also derived. The improved fit from CSF modeling compared to CMT modeling for glacial earthquakes comes despite a reduction in free parameters, suggesting that the source process represented by the CSF model provides a more appropriate representation of the source physics.

[11] We perform full-waveform inversions using the CSF approach for events initially identified by surface-wave detection, as described in Section 2.1. Our approach follows closely that used for standard CMT analysis by the Global CMT project [Dziewonski et al., 1981; Ekström et al., 2005], with the exception that we invert for CSF rather than CMT parameters. We interactively select records of intermediateperiod surface waves in the period band $40-150 \mathrm{~s}$. Records are selected from vertical and horizontal components of stations of the IRIS-USGS GSN, Geoscope, Geofon, and Canadian National seismograph networks located at less than $\sim 110^{\circ}$ epicentral distance. Stations are generally well distributed azimuthally. We evaluate the quality of our solutions based on their stability over multiple inversions and the misfit between predicted and observed waveforms, as for standard CMT solutions [Ekström et al., 2012].

[12] Glacial earthquakes occur at the Earth's surface, but the surface waves we use as data constraints have weak sensitivity to the depth of shallow sources. We calculate excitation functions in the Preliminary Reference Earth Model (PREM) [Dziewonski and Anderson, 1981], and the excitation changes little within the PREM upper crust. Tsai and Ekström [2007] found that CSF solutions for glacial earthquakes showed little variation when modeled at depths of 3-15 km. Our experience is consistent with this result, and we fix the source depths for the glacial earthquakes at $10 \mathrm{~km}$.

[13] The CSF approach we use also requires us to specify the shape of the force time history (source time function) for each event, similar to the moment-rate function that must be specified for CMT inversion. We choose the time function in a manner consistent with that of Tsai and Ekström [2007] so that our results may be directly compared. Because our analysis relies on surface waves at periods near the event source duration, the model source spectrum is sensitive to changes in the source time function, making such consistency important for comparison of CSF amplitudes. Tsai and Ekström [2007] used a boxcar source time function with a total duration of $50 \mathrm{~s}$, representing a constant force acting in one direction for $25 \mathrm{~s}$ followed by an equal-amplitude force acting in the opposite direction for the following $25 \mathrm{~s}$. We use 
த்

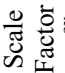

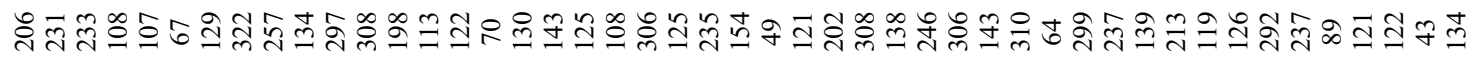

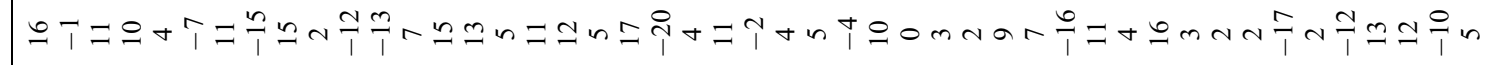

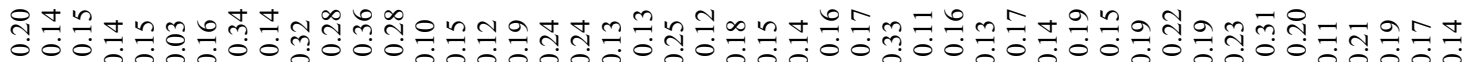

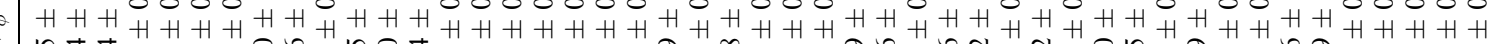

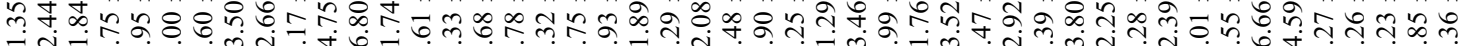
।

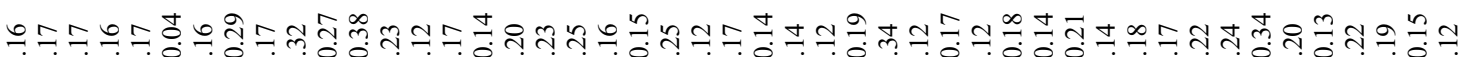

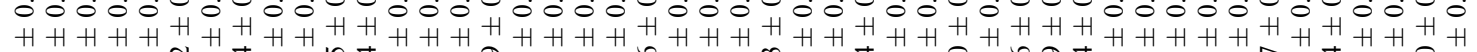

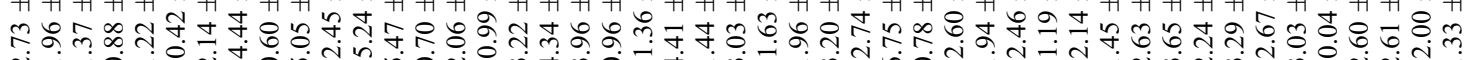
ĭ

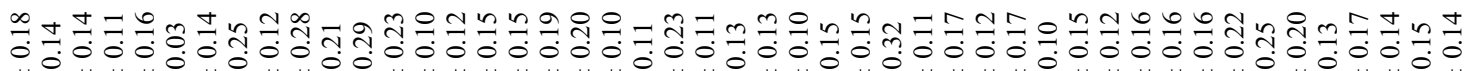

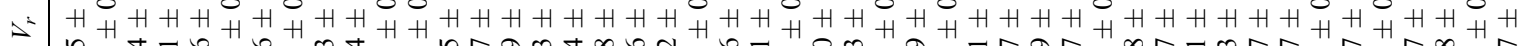

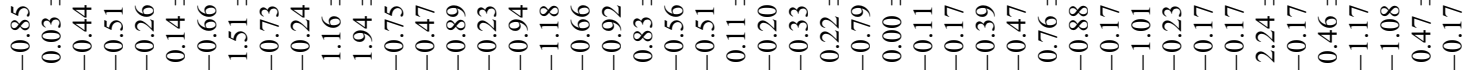

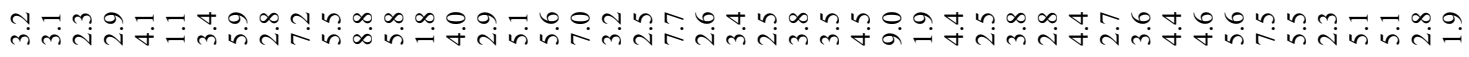

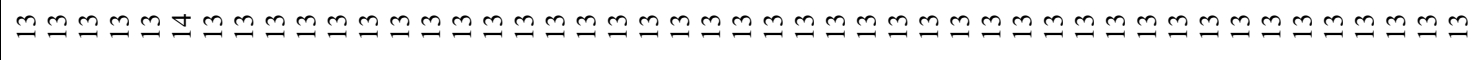

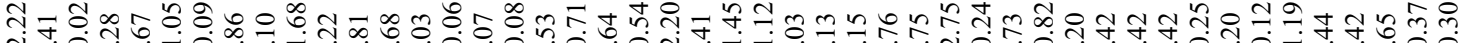
D

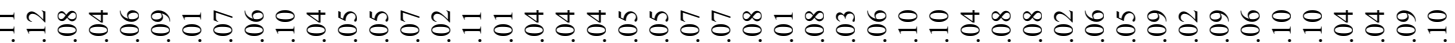
$H+H+H+H+H+H+H+H+H+H+H+H+H+H+H+H+H+H+H+H+H+H+H+H+H+H+H+H+H+H$ -

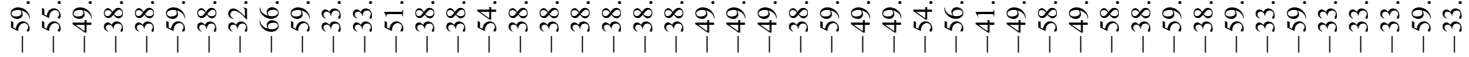

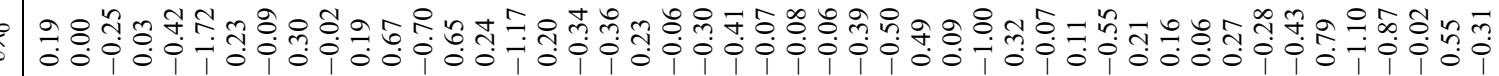

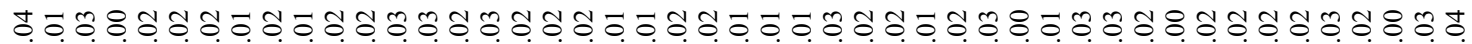

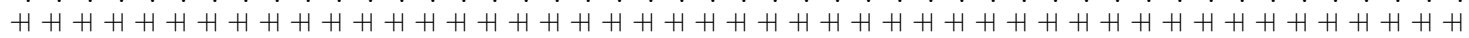

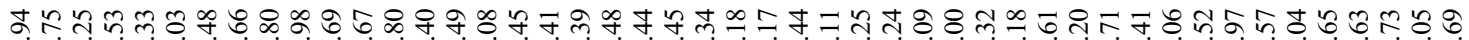
ผ

$\approx$ 住

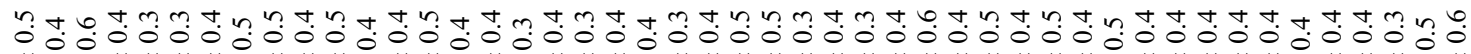

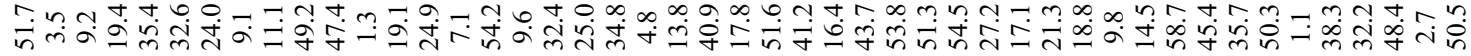

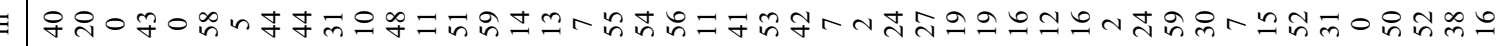
늡ํำ

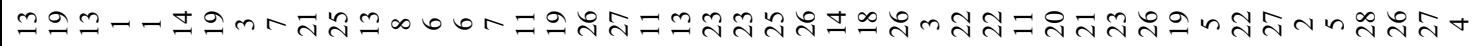




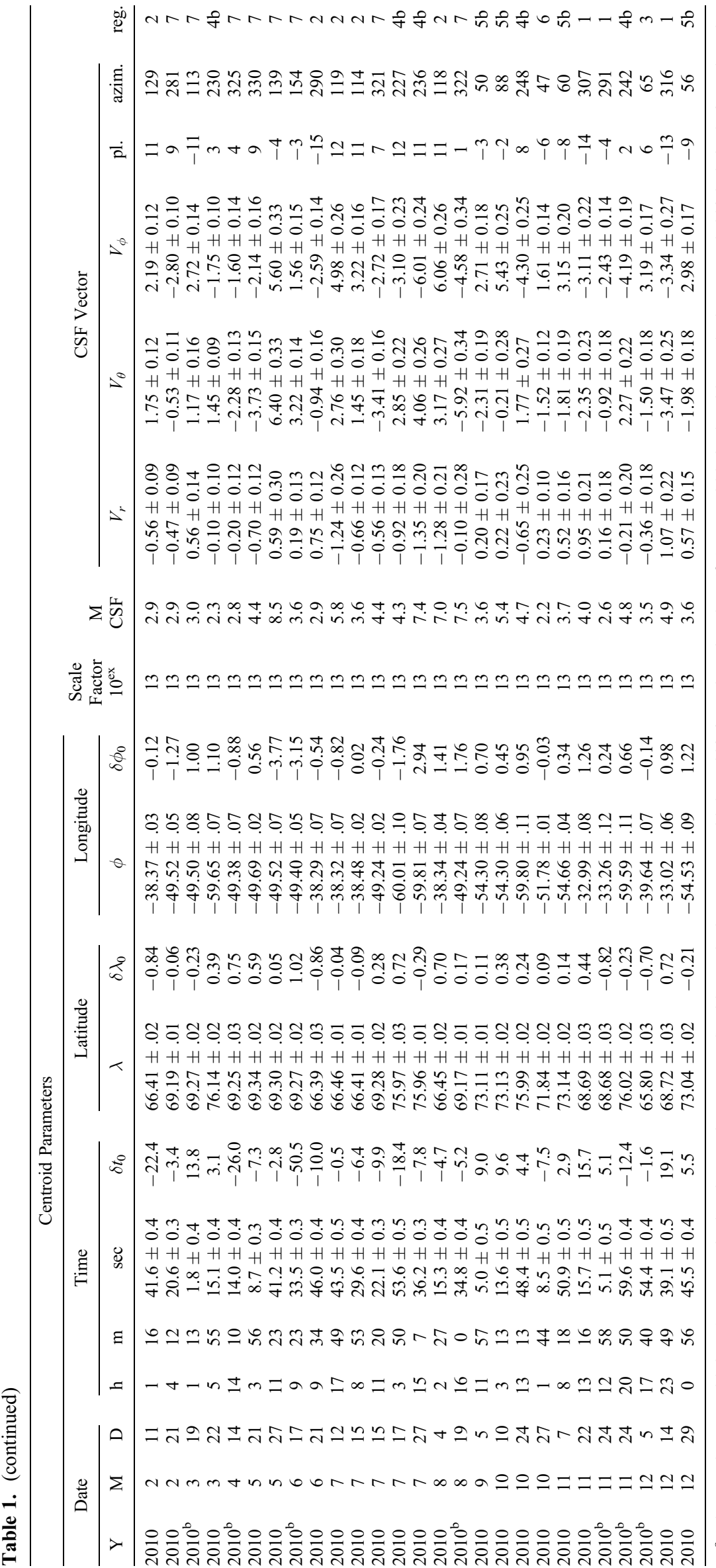

응

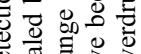

可 可言总的

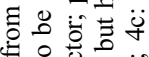

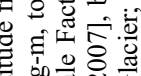

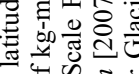

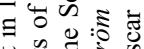

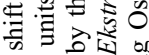

골.

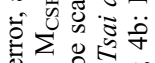

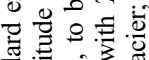

흔

क

30 형

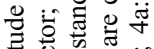

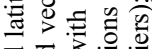

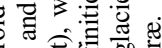

施

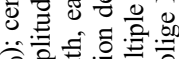

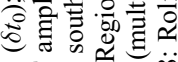

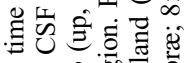

후워 $\theta$

过

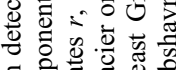

ह 중. 픔

4 on

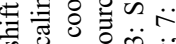

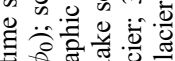

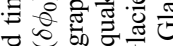

응

政

政

.응

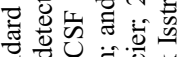

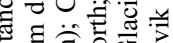

के

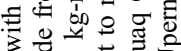

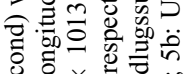

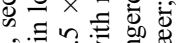

o n

青 11 .

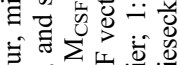

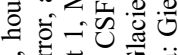

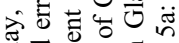

궁

进 要

क क

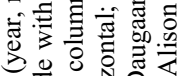

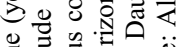

局层吅

흥 흐 흘 웡

局 
these same inputs for our waveform inversions to maintain consistency throughout the glacial-earthquake catalog.

\section{Results}

[14] We obtain satisfactory inversion results for all 121 glacial earthquakes identified by global surface-wave detection. Source parameters for the events are listed in Table 1 and the improved locations determined by waveform modeling are shown in Figure 1b. (Complete source parameters are also available online in electronic format on our website, http://www.globalcmt.org/.) Waveform modeling improves the accuracy of the earthquake locations and collapses the previously scattered event locations into tight clusters along the Greenland coast at the locations of large outlet glaciers. Nearly all of the earthquakes occur in the same source regions identified by Tsai and Ekström [2007]. However, we observe two events in regions not previously known to produce glacial earthquakes: a standard detection near Rolige Bræ in Scoresby Sound, and an NRT detection in Southeast Greenland between Hornemann Island and the mouth of Sermilik Fjord.

[15] Realistic assessments of the uncertainty in glacialearthquake locations derived from CSF analysis have previously been hampered by a lack of knowledge of the true source location and limited knowledge of the sources of noise and bias contributing to the true errors. Better knowledge of the glacial-earthquake source process and a larger sample of events allow us to assess both absolute and relative location errors here. Smith and Ekström [1997] studied the combined errors in hypocentral and CMT centroid locations for tectonic earthquakes, and found that errors of $\sim 25 \mathrm{~km}$ were typical. Because of the similarity in the CMT and CSF approaches, Tsai and Ekström [2007] adopted $25 \mathrm{~km}$ as an approximate estimate of the likely error in the CSF centroid locations. Nearly all of the events examined by Smith and Ekström [1997] were larger than those considered here, and we might expect larger errors for our smaller events; however, the CMT analyses in the Smith and Ekström [1997] study did not include the intermediate-period surfacewave constraints that both we and Tsai and Ekström [2007] employ, and which are likely to improve the location estimates.

[16] Under the assumption that all of the glacial earthquakes occur at glacier calving fronts, we use the published estimates of ice-front location of Joughin et al. [2008a], combined with the estimated earthquake centroids, to evaluate the absolute errors in our earthquake location estimates. Joughin et al. [2008a] used MODIS satellite imagery and an edge-detection algorithm, followed by visual verification, to map the locations of the calving fronts of Helheim and Kangerdlugssuaq glaciers as a function of time during 20012006. They obtained near-daily estimates from mid-April through early October each year, with less frequent estimates earlier and later in the year. Errors in the ice-front location estimates, which are measured near the center of the fjord, are on the order of the 250-m pixel size of the imagery. These errors are much smaller than the estimated errors in the earthquake centroid locations, as indeed are the total changes in calving-front location during any single season (typically
2-4 km), and we neglect these errors in our analysis, considering the measured ice-front locations at the times of the earthquakes to represent the true earthquake locations. We combine the results of Tsai and Ekström [2007] for 20012005 with our results from 2006 at these glaciers, and calculate the distance between the earthquakes and the ice-front locations reported closest in time to each earthquake. Varying the maximum time separation allowed between the earthquake and ice-front estimates changes the results very little, both because the changes in ice-front positions are small compared to the earthquake location errors and because, for most earthquakes, ice-front locations within a few days are available. We are able to make ice-frontearthquake comparisons for 65 events in 2001-2006 at the two glaciers considered. We find a median earthquake mislocation of $12 \mathrm{~km}$ and a mean of $15 \mathrm{~km}$, and that $90 \%$ of the earthquake locations lie within $24 \mathrm{~km}$ of the ice front and $95 \%$ within $35 \mathrm{~km}$. The sources of error in the location estimates are unlikely to vary significantly across Greenland, and we believe these estimates of location accuracy can be applied to the full data set of Greenland glacial earthquakes analyzed here, and previously by Tsai and Ekström [2007]. Our results also suggest that, although the glacial earthquakes are small in comparison with the tectonic events studied by Smith and Ekström [1997], the inclusion of intermediateperiod surface waves in the analysis allows us to achieve similar or slightly better absolute location accuracy.

[17] At many glaciers, the distribution of event locations is asymmetric, with the location distribution elongated approximately along the glacier-flow direction. This is evident in Figure 2, which shows glacial earthquakes at three of the most active glaciers in Greenland: Helheim Glacier, Kangerdlugssuaq Glacier, and Kong Oscar Glacier. These glaciers have produced sufficient numbers of events to allow meaningful analysis of patterns in the event locations. We calculate the directions of minimum and maximum variance in the distribution of event locations for each glacier, and fit a Gaussian function to the distribution projected onto each direction. We then calculate the standard deviation in the location distribution in each direction. The standard deviations $(\sigma)$ in the direction of minimum variance range from $\sim 4.5 \mathrm{~km}$ at Kong Oscar to $\sim 7.0 \mathrm{~km}$ at Helheim, and in the direction of maximum variance $\sigma$ ranges from $\sim 8.0 \mathrm{~km}$ at Kong Oscar to $\sim 10.0 \mathrm{~km}$ at Kangerdlugssuaq. If all of the earthquakes at a given glacier occurred at the same location, the variance in the event distribution could be taken as a measure of relative location error. The true event locations are unlikely to be identical, in which case the variances we calculate will overestimate the relative location error. Indeed, we find that the direction of maximum variance in the distribution of event locations corresponds to an azimuth subparallel to the fjord walls near the terminus of each glacier as measured from satellite imagery, suggesting a contribution to the variance from motion of the calving front, as described further in section 4 . With or without this additional variance, we conclude that the relative location error is smaller than the absolute location error.

[18] The improved accuracy of the earthquake locations we obtain, as well as the clustering of events, allows us to associate each glacial earthquake with a specific glacier with 

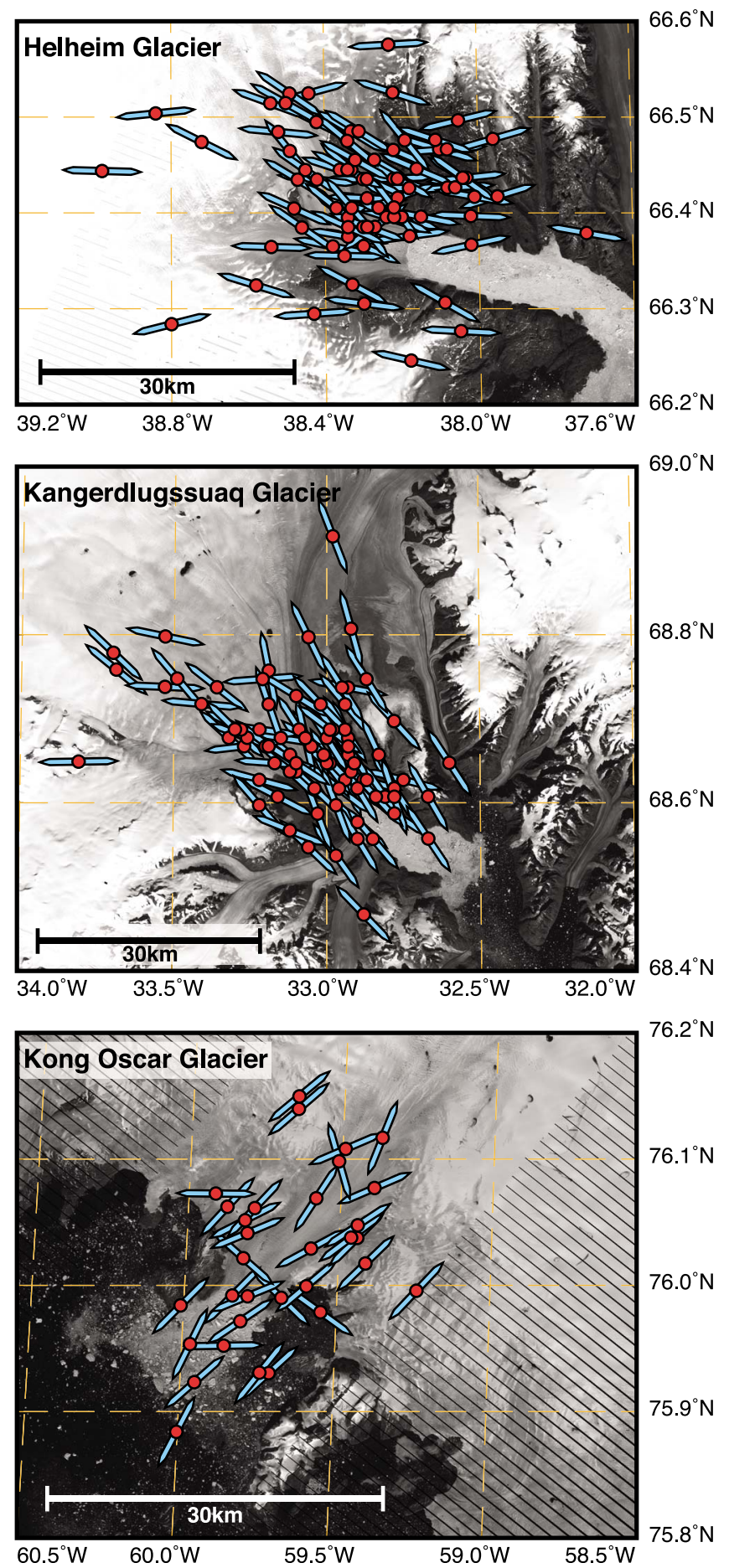

Figure 2. Distribution of glacial earthquakes, 1993-2010, at three glaciers: (top) Helheim Glacier, (middle) Kangerdlugssuaq Glacier, and (bottom) Kong Oscar Glacier. In each map, the locations of glacial earthquakes are shown as red dots, and the orientations of the force vectors associated with each event as blue bars. Because we consider the force directions to have a $180^{\circ}$ ambiguity for a given event (see text), we plot only the vector orientation here. The background images for each map are Landsat images obtained during August 2005 , on the 4 th, 15 th, and $22 \mathrm{nd}$, respectively. a high degree of confidence. As illustrated in Figure 1, it would be difficult to associate many events with a specific source glacier using the initial detection locations. This is particularly true for events located in Northwest Greenland and central East Greenland. In Northwest Greenland, locations derived from surface-wave detection are scattered, and outlet glaciers are closely spaced. In central East Greenland detection locations often lie roughly equidistant from Kangerdlugssuaq Glacier, several glaciers that terminate in Scoresby Sound, and glaciers associated with the Geikie Plateau. In both regions, locations derived from full-waveform inversion are sometimes more than $100 \mathrm{~km}$ from the surfacewave-detection locations, and the events are not always found to be associated with the glacier nearest the surfacewave detection location. In most cases, full-waveform inversion provides locations that are sufficiently accurate to eliminate ambiguity as to the source glacier for each event, and we indicate with which glacier we have associated each event in Table 1.

[19] Consistent with previous studies, we find that the force vectors for the glacial earthquakes are generally oriented in the glacier-flow direction, perpendicular to the calving front, as illustrated in Figure 2 for three very active glaciers. Similar to the results of Tsai and Ekström [2007], our solutions show force vectors that are both anti-parallel and parallel to glacier flow. While we report the best-fitting solution for each event, in many cases there also exists a similarly fit solution with a force vector rotated $\sim 180^{\circ}$ in azimuth. These secondary solutions show only very small location shifts, but are shifted by $\sim 25 \mathrm{~s}$ in time. The combination of the source phase shift and the time shift results in nearly the same predicted surfacewave phase at the receiver for both solutions at the dominant surface-wave period of $\sim 50 \mathrm{~s}$. Because the difference in the misfit between the two solutions is small, we consider there to be a $180^{\circ}$ ambiguity in force direction in our results. We also find that the force vectors are close to horizontal, with a mean plunge angle of less than $10^{\circ}$.

[20] The CSF amplitudes we derive lie between $0.1 \times 10^{14} \mathrm{~kg}-\mathrm{m}$ and $1.1 \times 10^{14} \mathrm{~kg}-\mathrm{m}$, with a median value of $3.5 \times 10^{13} \mathrm{~kg}-\mathrm{m}$. This is similar to the amplitudes obtained by Tsai and Ekström [2007], with the exception that those authors observed a small number of larger events, with magnitudes in the range $1.1 \times 10^{14} \mathrm{~kg}-\mathrm{m}$ to $2.0 \times 10^{14} \mathrm{~kg}-\mathrm{m}$. As described in Section 2, the amplitudes we obtain are sensitive to the choice of source duration, because the source duration is similar to the shortest-period data included in our analysis. We tested the effect of variations in the chosen source duration by performing additional inversions using a source model with durations $20 \%$ shorter (40 s) and $20 \%$ longer $(60 \mathrm{~s})$ than the $50 \mathrm{~s}$ duration used for our final solutions. We find that a $20 \%$ decrease in the source duration reduces the CSF amplitude of the glacial earthquakes by $\sim 20 \%$, while a $20 \%$ increase in modeled source duration results in an increase in the CSF amplitudes of $\sim 30 \%$. The remaining source parameters and the fit to the data are affected very little by the change in source duration. Like Tsai and Ekström [2007], we conclude that a duration of $50 \mathrm{~s}$ is appropriate as a general model for glacial earthquakes in Greenland, though individual events may be better explained by shorter or longer durations. Obtaining more detailed constraints on the force time history of glacial earthquakes will likely require the use of recordings at regional distances, 


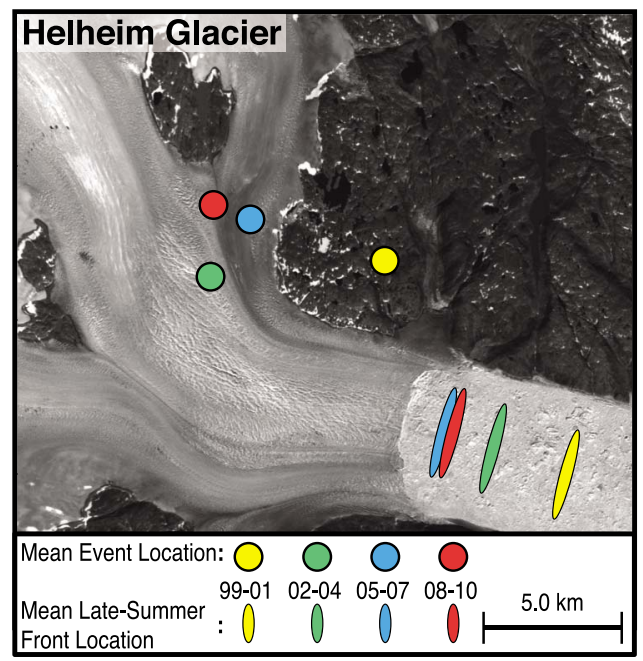

Figure 3. Comparison of changes in locations of glacial earthquakes and glacier calving front at Helheim Glacier, 1999-2010. Circles indicate the mean location of glacial earthquakes during each three-year time period; ellipses indicate the mean mid-August calving-front location as measured from Landsat imagery. The range and orientation of changes in event location are similar to changes in the position of the calving front. The mean earthquake location for 2002-2004 is dominated by events in 2004; the calving-front location averages are not weighted. Background is a Landsat image from 4 August, 2005.

where the weak higher-frequency signals will be of higher amplitude.

\section{Discussion}

[21] Previous systematic studies of glacial earthquakes in Greenland [Tsai and Ekström, 2007] were made under the operating hypothesis that the earthquakes were caused by sudden sliding of the glacier trunk. More recent studies demonstrating that the toppling and seaward acceleration of newly calved icebergs provides a more likely explanation for the observed seismicity have focused on small numbers of glacial earthquakes at a handful of individual glaciers [e.g., Amundson et al., 2008; Joughin et al., 2008a; Nettles et al., 2008a]. An initial re-examination of patterns of glacialearthquake occurrence over time [Nettles and Ekström, 2010] supported the iceberg-calving hypothesis, but only employed a full set of glacial-earthquake source parameters through 2005 . Here, we combine the 121 source-parameter solutions presented in Section 3 (Table 1) with the 184 solutions of Tsai and Ekström [2007] to assess the consistency of this larger data set with the iceberg-calving model. We then examine spatial and temporal patterns of glacial-earthquake occurrence throughout Greenland, and compare observed spatiotemporal patterns to changes observed by satellite remote sensing at several glaciers of particular interest.

\subsection{Glacial Earthquake Source Characteristics}

[22] Current models suggest that glacial earthquakes in Greenland occur at the calving fronts of large marineterminating glaciers during large calving events [Nettles et al., 2008a; Joughin et al., 2008a; Amundson et al., 2008; Tsai et al., 2008; Nettles and Ekström, 2010]. During seismogenic calving events, icebergs the full thickness of the glacier detach from the calving front and overturn due to gravitational instability. Since the iceberg is held against the calving front by resistance from water and floating ice in the fjord, the system is well coupled to the solid earth as the iceberg capsizes. The forces exerted on the calving front by the overturning block are opposite to the motion of the iceberg's center of mass and are roughly perpendicular to the calving front, oriented inland, and approximately horizontal to the surface of the earth. We find that the locations and source parameters for the 1993-2010 glacial-earthquake data set are consistent with this model.

[23] We observe that the locations of glacial earthquakes throughout Greenland are consistent with earthquake occurrence at glacier calving fronts. Nearly all earthquakes are located within $\sim 35 \mathrm{~km}$ of the ice margin, similar to the absolute location uncertainty estimated with and without the assumption that the earthquakes occur at a calving front. As described in Section 3, the distribution of glacial-earthquake locations is asymmetric, with the direction of maximum location variance corresponding to a direction approximately perpendicular to the calving front. That is, scatter in glacialearthquake locations is narrowest across each glacier's width, and elongated perpendicular to the glacier calving front. Tsai and Ekström [2007] made a similar observation at Kangerdlugssuaq Glacier and, using the now-discarded bedsliding model, attributed this distribution to event occurrence at different points along the glacier. We interpret the elongation in the glacier-flow direction as resulting from variations in the calving-front location over time.

[24] At the three glaciers with the largest numbers of events recorded - Kangerdlugssuaq Glacier, Helheim Glacier, and Kong Oscar Glacier - we observe that the difference in scatter between the along-flow and cross-flow directions is similar to the amplitude of observed variations in the locations of the glacier calving fronts $(3-5 \mathrm{~km})$ over the 18 years considered. In addition, the geometry of changes in mean earthquake location is similar to the change in the calving-front location over time. This correspondence is shown for Helheim Glacier in Figure 3, where we compare the mean event locations in three-year intervals to the mean late-summer calving-front locations over the same intervals. To determine the late-summer-average front location, we digitized Landsat 7 images taken in early August of each year, and recorded the position of the glacier midway across the fjord. We then averaged these locations in 3-year bins. While the average earthquake locations are offset somewhat from the calving front due to absolute location errors, they show a similar variation in location in both amplitude and direction. Kangerdlugssuaq Glacier and Kong Oscar Glacier show similar trends, and we infer that the greater scatter in locations perpendicular to the glacier calving fronts is related to variation in the location of the calving front over time.

[25] Previous workers [Ekström et al., 2003; Tsai and Ekström, 2007] interpreted the orientation of the force vectors to result from sliding at the glacier bed in the glacier flow direction. In contrast, we interpret the orientation of the forces to result from the direction of motion of icebergs as they capsize. As predicted by the iceberg-calving model, most force directions in the 18-year data set are perpendicular to 

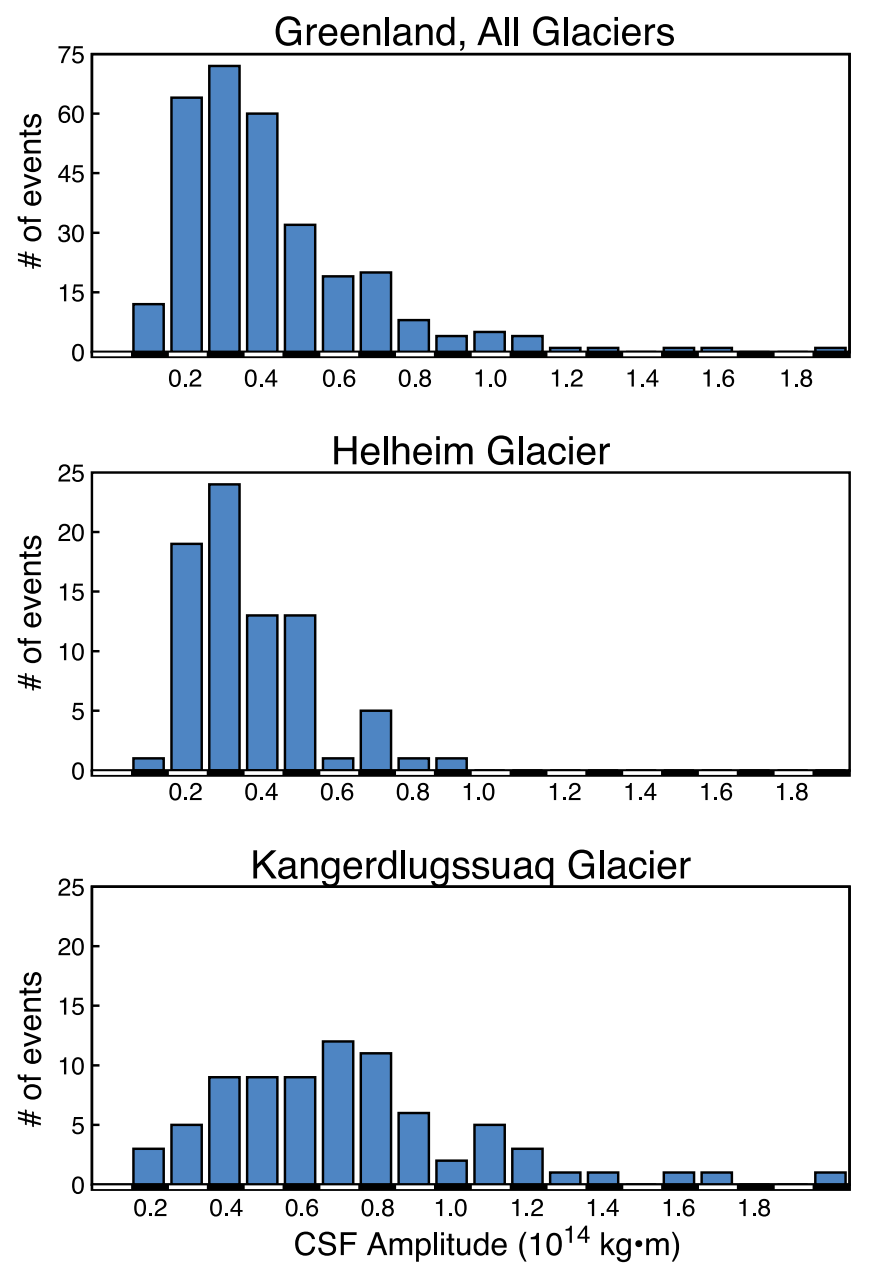

Figure 4. Size distribution for (top) all Greenland glacial earthquakes, (middle) Helheim Glacier and (bottom) Kangerdlugssuaq Glacier from 1993-2010. We observe a narrow range of event sizes, with a peak at a value that is twice as large at Kangerdlugssuaq as at Helheim. Kangerdlugssuaq produced 79 events during this time period, Helheim produced 78 events, and Greenland a total of 305 events.

the calving fronts of the source glaciers. We observe events showing inland-"uphill" and seaward-"downhill" orientations in near-equal numbers. As discussed earlier, we believe this result can be explained by the surface-wave radiation patterns of CSF events, and the spectra of these events, as the data are also fit reasonably well by a solution with the opposite force direction, shifted $\sim 25 \mathrm{~s}$ in time. A very small number of earthquakes show force directions rotated $\sim 90^{\circ}$ with respect to the calving front (a handful of these events can be seen in Figure 2), possibly as the result of complex calving geometry. Chen et al. [2011] also detected a small number of glacial-seismic events in Antarctica that share this peculiar geometry, with an unknown physical mechanism. While we believe these events warrant future study, the overwhelming majority of glacial earthquakes show force directions consistent with the iceberg-calving model.

[26] The CSF amplitudes we obtain for the glacial earthquakes are also consistent with the calving model, in which the size of an earthquake must be limited by glacier geometry. Figure 4 shows size-frequency distributions for
Kangerdlugssuaq Glacier, Helheim Glacier, and the complete glacial-earthquake catalog. The distribution of sizes for glacial earthquakes contrasts strongly with that for tectonic earthquakes, which range in size over more than 10 orders of magnitude and for which the number of earthquakes typically increases by a factor of ten for each one-unit decrease in magnitude [e.g., Gutenberg and Richter, 1944; Ekström et al., 2012]. For glacial earthquakes, the range of observed sizes is small, approximately one order of magnitude. For each region, the size distributions show a peak with a rapid decline at larger and smaller sizes. The peak occurs at different sizes in different regions: at Kangerdlugssuaq, the peak occurrence is at $0.7 \times 10^{14} \mathrm{~kg}-\mathrm{m}$, while Helheim and the complete catalog are both peaked at a value half as large, $0.3 \times 10^{14} \mathrm{~kg}-\mathrm{m}$. The distribution is wider at Kangerdlugssuaq than at Helheim, with a slower fall off toward smaller and larger sizes. These two large glaciers influence the shape of the Greenland-wide distribution, but this distribution retains a similar shape when they are removed. The general shape of the distributions and the range of sizes observed remain very similar to those from the Tsai and Ekström [2007] data set, despite a near doubling in the number of events. The shape of the size-frequency distributions for glacial earthquakes is likely to reflect a combination of physical bounds on earthquake size and, at the lower end, limitations on detection. Both the differences in the size distribution between glaciers and the fact that the distributions are peaked well above the detection threshold suggest that the decrease in numbers of events at smaller sizes results in part from a true paucity of smaller events, rather than just from the difficulty of detecting smaller events.

[27] We hypothesize that each glacier will possess a sizefrequency distribution with a characteristic shape and peak dependent on its size and geometry, but that the overall variation in these distributions will remain small owing to the limited range of sizes of glaciers producing glacial earthquakes. In order to produce a glacial earthquake, we expect that the calved block must remain substantially intact as it capsizes, in which case, the strength of glacial ice will impose a limit on the minimum size of seismogenic blocks. The upper limit of glacial-earthquake size is likely to be a function of glacier thickness and width, with thicker glaciers producing larger earthquakes [e.g., Nettles and Ekström, 2010; Burton et al., 2012]. The glacier thickness controls the along-flow width of seismogenic blocks, because the tendency to capsize depends on the aspect ratio of the block. Blocks that are larger than $\sim 80 \%$ of the glacier thickness in the along-flow direction are unlikely to capsize [MacAyeal et al., 2003], though the presence of ice mélange may modify the aspect ratio at which capsize is most likely to occur [Amundson et al., 2010]. The glacier thickness and width are also likely to control the cross-flow dimension of the calved block, which can in any case not exceed the glacier width. The exact relationship between block mass and glacial-earthquake size is unknown, and is likely to depend on additional factors, including hydrodynamic controls [e.g., Amundson et al., 2012]. However, glacier geometry provides a simple and plausible explanation for the small range of observed earthquake sizes, the variation in event sizes between glaciers, and the small sizes of the largest earthquakes observed. Such geometrical control is also consistent with the occurrence of larger earthquakes at 

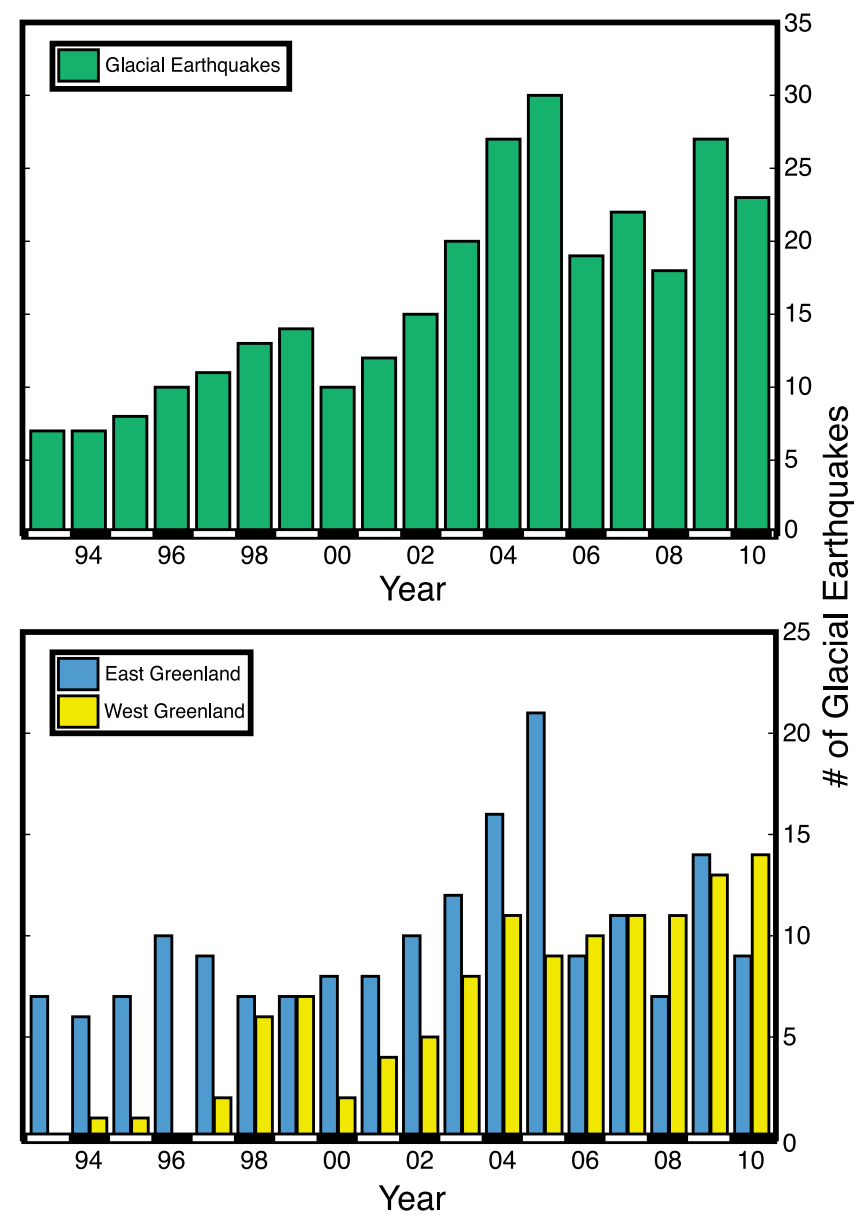

Figure 5. Glacial-earthquake production in Greenland, 1993-2010. (top) Yearly occurrence of glacial earthquakes across Greenland. Note the decline in events from 2005 to 2006, with subsequent production at levels similar to 2003-2004. (bottom) Yearly occurrence of glacial earthquakes in West Greenland and East Greenland. Note the differing trends after 2005, as production in West Greenland continues to rise, while production in East Greenland is more variable.

Kangerdlugssuaq Glacier than Helheim Glacier, but better information about bed topography at multiple glaciers is required to assess our hypothesis quantitatively.

\subsection{Spatial and Temporal Changes in Event Distribution}

[28] Combining our results for 2006-2010 with those of Tsai and Ekström [2007] for 1993-2005 allows us to assess spatial and temporal variability in glacial-earthquake production over an 18-year period, and to compare these changes with other observations of changes in glacier behavior. In this section, we provide a brief description of the spatiotemporal patterns we find in the 18 -year combined catalog, and in the following section address links to glacier dynamics. We include only those earthquakes from our study (109 events) that were detected in a manner consistent with earlier studies. Ekström et al. [2006] demonstrated the lack of a temporal or seasonal trend in the event-detection threshold for earthquakes in 1993-2005, for the same detection procedures we use here. The global seismic network configuration was stable over the period 2005-2010, and we have confirmed that the detection threshold also has remained stable. We are thus able to assess trends over 18 years of glacial-earthquake production, with a total of 293 events. The number of earthquakes occurring in each year is shown in Figure 5. Previous studies noted an increase in the number of glacial earthquakes occurring Greenland-wide during the years 1993-2005, peaking at 30 events in 2005 [Ekström et al., 2006]. Since 2005, glacial earthquakes have continued to occur at a high rate, but below this peak level. Earthquake production in 2006-2010 was similar to that in 2003-2004, with the mean annual number of glacial earthquakes during this period more than double that in 1993-2000.

[29] Glacial-earthquake occurrence is also shown for East and West Greenland separately in Figure 5. From 1993 to 1999 glacial-earthquake production in both East and West Greenland was low and variable, but with East Greenland producing significantly more glacial earthquakes annually than West Greenland. From 2000 to 2005, trends in earthquake production in East and West Greenland were similar, with annual production increasing rapidly. Both coasts contributed roughly equally to the inter-annual Greenlandwide increases seen during that time, though the fractional increase was greater in West Greenland than East Greenland owing to the former's lower average rate of production prior to 2000. Since 2006 East Greenland and West Greenland have shown different trends.

\subsubsection{East Greenland}

[30] East Greenland produced 6-10 glacial earthquakes per year from 1993-1999, increasing rapidly to a peak of 21 in 2005 (Figure 5). A decline of nearly $60 \%$ then occurred from 2005 to 2006 . Throughout the entire data set, glacialearthquake production in East Greenland has been restricted to a small number of glaciers, with Helheim Glacier and Kangerdlugssuaq Glacier being the most important glacialearthquake producers in the region (Figure 6). Changes in annual numbers of glacial earthquakes in East Greenland are primarily driven by changes at these two glaciers, and the drop after 2005 mainly reflects decreases in glacialearthquake activity at Helheim and Kangerdlugssuaq. After 2005 we observe a cessation of glacial-earthquake production at Daugaard Jensen Glacier, but this glacier has never produced more than two glacial earthquakes in a single year. We also observe a single glacial earthquake at previously inactive Rolige Bræ. These changes are minor, and did not strongly affect overall glacial-earthquake production in East Greenland. Since 2006 production has been variable, but remains elevated when compared to pre- 2000 rates. Kangerdlugssuaq Glacier has shown relatively steady production inter-annually since 2006, while Helheim Glacier has shown large inter-annual changes, leading to the overall variability in annual production in East Greenland since 2006.

\subsubsection{West Greenland}

[31] In West Greenland, glacial-earthquake production was minimal prior to 2000, with only four events recorded prior to 1998 (Figure 5). From 2000-2004, production increased steadily, reaching 12 events in 2004 followed by a small decrease in 2005. This period coincides with the Greenland-wide increase in glacial earthquakes. After 2005, in contrast with the sharp decline seen in East Greenland, glacial-earthquake production in West Greenland remained 


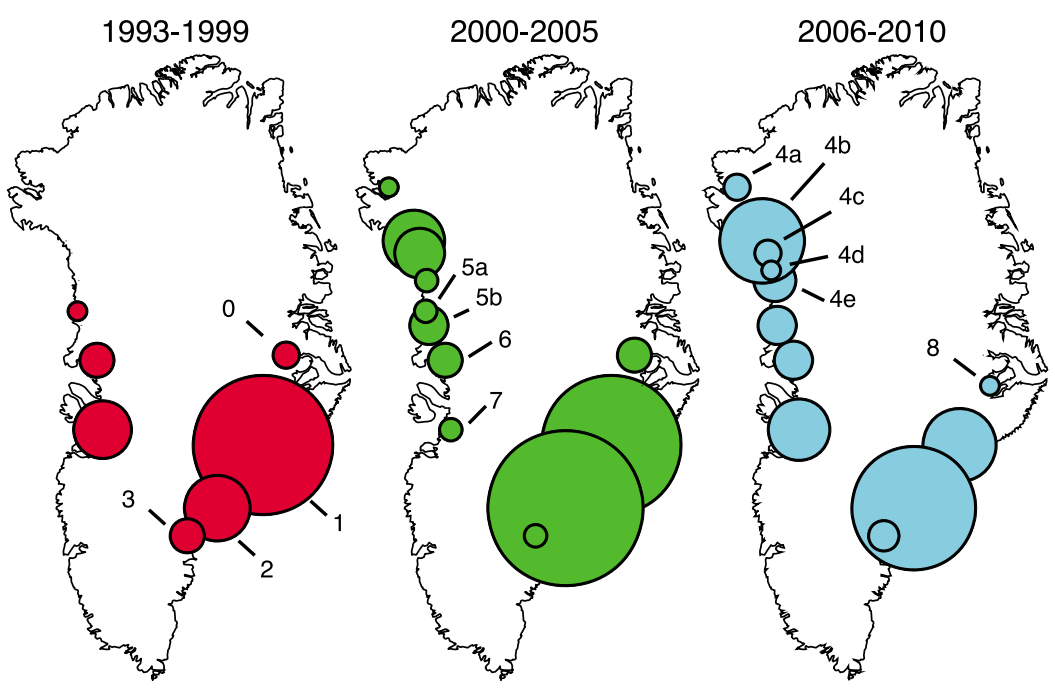

Figure 6. Three phases of glacial-earthquake production in Greenland. Each glacier is represented by a single dot, with sizes scaled linearly by the number of glacial earthquakes occurring at the glacier during each time period. The scaling is consistent between time periods; numbers range from 1 earthquake at Rolige Bræ (region 8) during 2006-2010 to 36 earthquakes at Helheim Glacier (region 2) during 2000-2005. From 1993-1999, production was relatively steady and concentrated in Southeast Greenland, with some production at a handful of larger glaciers in central West Greenland. From 2000-2005, glacialearthquake production increased Greenland-wide, as many previously inactive glaciers in Northwest Greenland began to produce glacial earthquakes regularly. From 2006-2010, production declined in East Greenland, but continued to rise in West and Northwest Greenland. Glaciers are labeled as in Table 1: 0: Daugaard-Jensen Glacier; 1: Kangerdlugssuaq Glacier; 2: Helheim Glacier; 3: Southeast Greenland (multiple glaciers); 4a: Tracy Glacier; 4b: Kong Oscar Glacier; 4c: Sverdrup Glacier; 4d: Hayes Glacier; 4e: Alison Glacier; 5a: Giesecke Bræer; 5b: Upernavik Isstrøm; 6: Rinks Glacier; 7: Jakobshavn Isbræ; 8: Rolige Bræ.

high and continued to show increases following 2005, reaching a peak of 14 in 2010.

[32] The continued increase in West Greenland glacial earthquakes is accompanied by a change in spatial distribution. Prior to 2000, the majority of glacial earthquakes in West Greenland occurred at Jakobshavn Isbræ (Figure 6). Jakobshavn is the largest outlet glacier in Greenland, and is responsible for the spike in glacial earthquakes observed in West Greenland during 1998 and 1999. However, during the Greenland-wide rapid increase recorded in 2000-2005, Jakobshavn Isbræ was conspicuously absent from the glacial-earthquake catalog (Figures 7 and 8). Even after becoming active again in 2005, Jakobshavn accounted for only $28 \%$ of West Greenland glacial earthquakes from

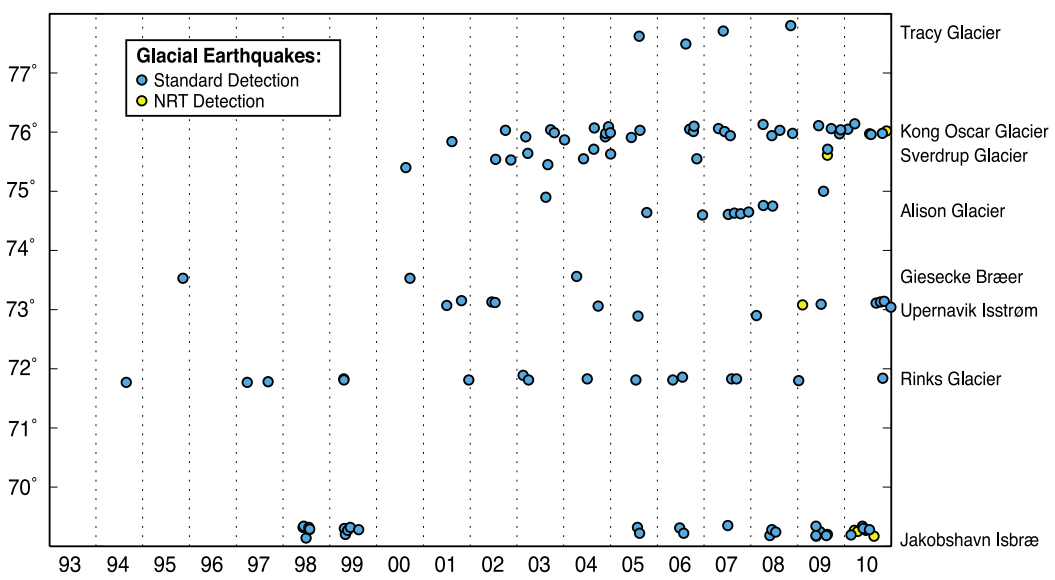

Figure 7. Latitude of glacial earthquakes in West Greenland vs. time of occurrence. Standard detections are indicated in blue, NRT detections are indicated in yellow; source glaciers are labeled on the right. The coast of West Greenland is oriented approximately North/South, thus glaciers are separated by latitude. Production of glacial earthquakes has spread northward over time, with multiple glaciers producing glacial earthquakes after previous quiescence. 

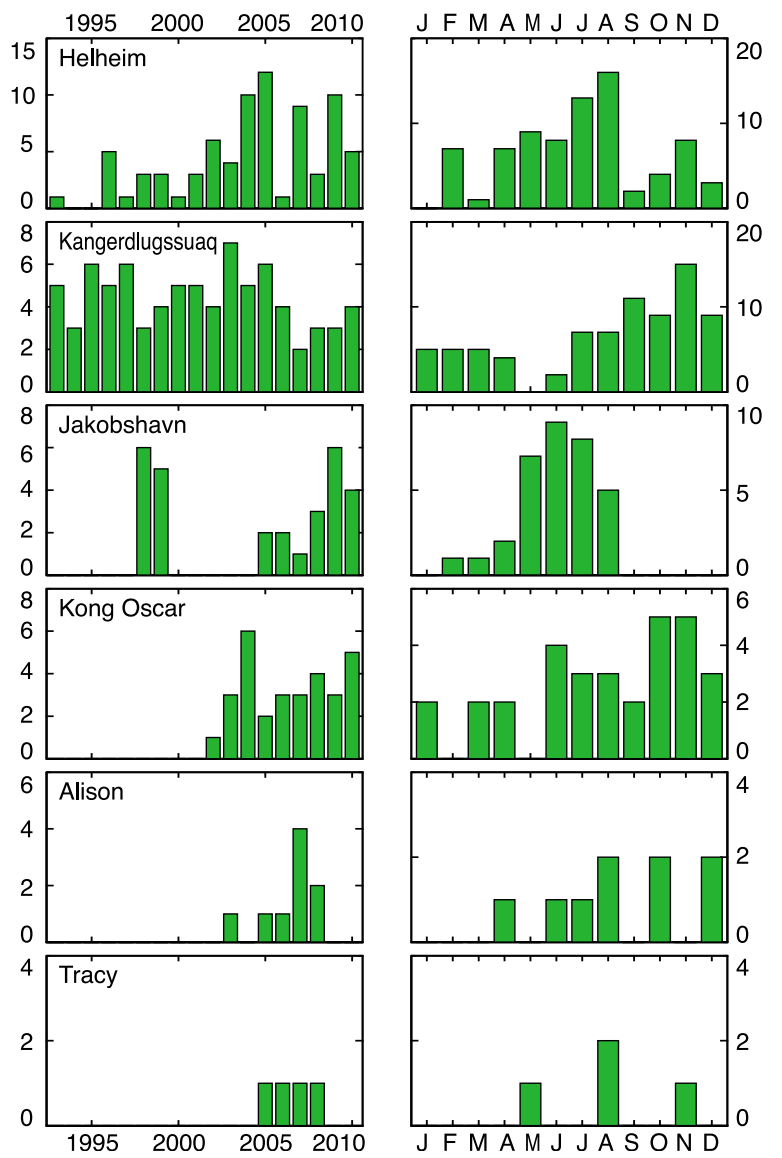

Figure 8. (left) Yearly and (right) monthly distributions of glacial earthquakes at the six glaciers discussed in detail in section 4.3 .

2005-2010, contrasting sharply with the $65 \%$ of glacial earthquakes in West Greenland for which it accounted prior to 2000 .

\subsubsection{Spread of Glacial-Earthquake Production}

[33] Although the dominant source of glacial earthquakes in West Greenland prior to 2000 was Jakobshavn Isbræ, the source of the rapid increase and sustained high rate of glacialearthquake production in West Greenland during 2000-2010 has been other, smaller, previously inactive glaciers in Northwest Greenland. These glaciers had no significant glacial-earthquake production prior to 2000 , and accounted for only one glacial earthquake during the 1990s. Over the last decade, the number of glacial earthquakes at these glaciers has increased dramatically. From 2000-2010, 66 glacial earthquakes occurred at previously quiescent glaciers, representing $>30 \%$ of all glacial-earthquake production since 2000 , and $>40 \%$ of glacial earthquakes since 2006 . At least four glaciers have produced multiple events during multiple years; Kong Oscar Glacier alone, quiescent prior to 2002 , accounts for 30 events from 2002-2010. The onset of glacial-earthquake production at these glaciers represents a major expansion in the number of glaciers producing glacial earthquakes and the geographic range of those glaciers.

[34] We identify three distinct time periods in the glacialearthquake catalog, characterized by different trends and distributions of production, as shown in Figure 6. The first, $1993-1999$, is characterized by relatively steady rates of production Greenland wide, dominated by the influence of the three largest glaciers in Greenland, Kangerdlugssuaq, Helheim, and Jakobshavn. The second phase, 2000-2005, corresponds to the Greenland-wide increase in the annual occurrence of glacial earthquakes, showing marked increases in both the number and spatial extent of glacial earthquakes. During this period, glacial earthquakes began to spread into Northwest Greenland, and glaciers there to produce substantial numbers of glacial earthquakes (Figure 6). The third phase, lasting from 2006 to at least 2010, is defined by continued high rates of production from glaciers in West Greenland, with East Greenland producing approximately stable numbers of glacial earthquakes, but at a rate lower than that seen in 2003-2005. This phase shows the rise in importance of smaller glaciers in Northwest Greenland, and the decline in importance of the large glaciers in both West and East Greenland, with Helheim and Kangerdlugssuaq becoming less active and Jakobshavn Isbræ ceasing to dominate glacial-earthquake activity in West Greenland.

[35] Within West Greenland, the pattern of glacialearthquake occurrence also shows a northward expansion since 2000. Figure 7 shows the latitude of glacial earthquakes in West Greenland plotted versus the time of their occurrence, showing that the onset of glacial-earthquake production has proceeded rapidly northward since 1994 . As the West Coast of Greenland is oriented nearly North/South, each horizontal line of events shown in this figure may be taken to represent an individual glacier. During the 2000s, after previous quiescence, multiple glaciers began and have maintained a multiannual period of regular glacialearthquake production. The current maximum latitude of observed glacial earthquakes is $\sim 78^{\circ} \mathrm{N}$.

\subsection{Link to Glacier Dynamic Behaviors}

[36] The source characteristics of the glacial earthquakes in our data set, including locations, force directions, and size distributions, are consistent with a physical mechanism of capsize of thick, newly calved icebergs at glacier calving fronts. This interpretation suggests that earthquake production should increase when calving rates increase and glacier fronts retreat, either seasonally or inter-annually, and an initial assessment by Nettles and Ekström [2010] found that this relationship holds in at least a general sense. However, it has also been suggested [Joughin et al., 2008a; Nettles and Ekström, 2010] that glacial earthquakes occur only when the calving front is near the grounding line. This may be the result of a change in calving style when the calving front is nearly grounded, such that most ice is lost by calving of narrow, gravitationally unstable icebergs, rather than wide, tabular icebergs. Such a change in calving style is often apparent in satellite imagery, an example of which is shown in Figure 9. Grounding or near grounding of the glacier calving front may also lead to better coupling to the solid earth, and thus more strongly observable seismic signals. Amundson et al. [2010] note, however, that calving fronts that are too strongly grounded are unlikely to produce icebergs that represent the full thickness of the glacier. By 'grounded or near grounded' in our discussion here, we refer to the situation relevant for many marine-terminating glaciers in Greenland, in which at least several hundred meters of ice can achieve a floatation condition between calving 

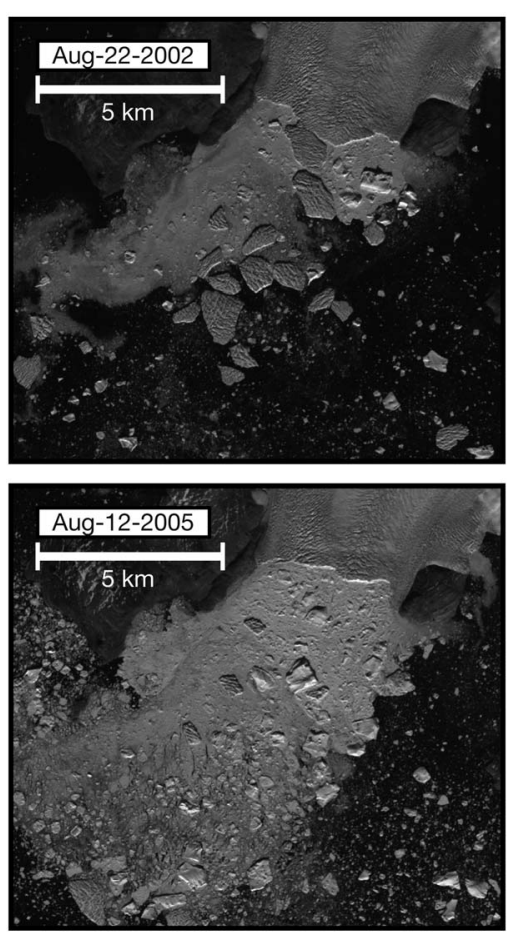

Figure 9. Two images of Kong Oscar Glacier demonstrating the visual difference between calving of (top) tabular and (bottom) capsizing icebergs. Tabular icebergs are typically larger and show the same surface texture as the source glacier. Capsized icebergs are typically smaller, appear brighter, and show a smooth surface texture. Image in Figure 9 (top) was captured a few months prior to the inferred transition to grounded calving, and the onset of glacial-earthquake production. Though one large capsized iceberg is visible, the proglacial mélange is dominated by tabular bergs. Image in Figure 9 (bottom), showing calving close to the grounding line, is dominated by capsized icebergs, though several smaller tabular icebergs are also present.

events, but the calving front remains close to the grounding zone.

[37] In several cases studied to date, at Jakobshavn Isbræ and Helheim Glacier [Amundson et al., 2008; Nettles et al., 2008a; Nettles and Ekström, 2010], an increase in glacier velocity has been observed to accompany seismogenic calving events. These increases are interpreted as the glacier's response to a decrease in resistive force when calving occurs. Nettles et al. [2008a] also observed an increase in the longitudinal strain rate associated with seismogenic calving. If these relationships are general, we expect to see increases in glacier velocity and glacier thinning accompanying increases in glacial-earthquake production. In this section, we compare patterns in the occurrence of glacial earthquakes with dynamic changes in Greenland's glaciers as observed by satellite and airborne remote sensing on a regional, and, in some cases, local, scale.

\subsubsection{Greenland-Wide and Regional Changes}

[38] Greenland-wide, the overall increase in glacial earthquakes from 2000 onward corresponds to a large increase in the number of glaciers in multiannual retreat [Howat and $E d d y, 2011]$. The increase in East Greenland earthquakes through 2005 coincides with the well-known retreats of Helheim Glacier and Kangerdlugssuaq Glacier [e.g., Howat et al., 2005; Joughin et al., 2008a]. The decrease in East Greenland glacial earthquakes after 2005 coincides with the stabilization, and in some cases, readvance of calving fronts in Southeast Greenland, as documented in surveys by Moon and Joughin [2008] and Seale et al. [2011]. A decrease in velocity and reduction in the rate of thinning was also observed at the Southeast Greenland glaciers at this time [Murray et al., 2010].

[39] The pattern of expansion of glacial-earthquake production into Northwest Greenland is also similar to trends seen in other observations. Northwest Greenland shows both the highest percentage of glaciers in retreat of any region in Greenland and the largest increase in the number of glaciers in retreat after 2000 [Howat and Eddy, 2011], the same time during which we observe the spread of glacial earthquakes into this region (Figure 6). After 2006, the average rate of retreat of glaciers in Northwest Greenland was larger than that in other parts of Greenland, and did not show a reduction in 2006-2007 when compared to 2000-2006 [Moon and Joughin, 2008]. Of the glaciers in this region showing the most significant calving-front retreats [Moon and Joughin, 2008] and trunk acceleration [Joughin et al., 2010], the majority were responsible for multiple glacial earthquakes.

[40] Satellite gravimetry has also shown mass loss from the northwestern portion of the Greenland Ice Sheet during this time period. Northwest Greenland showed an average net positive change in mass over the 10 years prior to 2002 , but a net mass loss from 2003-2005 and in later years [Luthcke et al., 2006; Wouters et al., 2008]. The onset time of this net mass loss is not well constrained, but satellite gravimetry and modeling of GPS-derived uplift data indicate a northward spread of mass loss into Northwest Greenland beginning around 2000 [Jiang et al., 2010] and increasing around 2005 [Khan et al., 2010].

\subsubsection{Helheim Glacier}

[41] Helheim Glacier is one of the largest and fastestflowing outlet glaciers in Greenland. It has seen significant changes over the last two decades and has been the subject of significant field and remote study since the mid 1990s. Glacial earthquakes have been studied more closely at Helheim than at any other glacier, and combined field and remotesensing observations there, along with similar observations at Kangerdlugssuaq Glacier and Jakobshavn Isbræ, provide much of the observational basis for our current understanding of the glacial-earthquake seismic source and glacier response. Studies using satellite and time-lapse imagery, field observations, fjord water-pressure monitoring, and seismic and GPS data [Joughin et al., 2008a; Nettles et al., 2008a; Nettles and Ekström, 2010; Hamilton et al., 2008] have demonstrated the coincidence of glacial earthquakes with large-scale calving events at Helheim during the summers of 2001-2008. Focused studies of individual earthquakes in 2007 and 2008 have also shown glacier acceleration coincident with glacial earthquakes [Nettles et al., 2008a, 2008b]. Here, we examine earthquake and glacier behavior on a broader timescale, over the full range of glacial-earthquake observations, from 1993-2010. Annual and seasonal patterns of glacial-earthquake production at Helheim are shown in Figure 8, with event locations shown in Figure 2. Helheim is responsible for a glacial earthquake in 
1993, the first year of the combined catalog of Tsai and Ekström [2007] and this study. No further events occurred until 1996, when there were 5 earthquakes. Since 1996, Helheim has produced earthquakes annually, with 76 events in 1996-2010, for a mean of 5.1 earthquakes/year during that time. Except for 1996, seismicity at Helheim remained low, at 1-3 events yearly, through 2001. In 2002, the number of earthquakes began to increase, with $6,4,10$, and 12 events in 2002-2005. Seismicity declined dramatically in 2006, to 1 event, and was variable in 2007-2010, ranging from $3-10$ events each year.

[42] Satellite observations show that the Helheim calving front advanced slightly between 1992 and 1995, then retreated in 1996, maintaining a similar minimum position until 2000, with seasonal oscillations of $\sim 2 \mathrm{~km}$ [Luckman et al., 2006]. During 1993-1998, the Helheim region thinned somewhat [Krabill et al., 1999]. Calving flux appears to have increased slightly in the mid- to late 1990s [Andresen et al., 2012], and the glacier accelerated slightly from mid-1995 to 1997 [Luckman et al., 2006]. The calving front also appears to have been grounded or near grounded in summer during the late 1990s, based on floatation levels and elevation profiles presented by Howat et al. [2005]. From 2001 to 2005, Helheim underwent significant retreat and thinning, as well as acceleration [Howat et al., 2005; Stearns and Hamilton, 2007; Joughin et al., 2008a], with the largest changes occurring in 2004-2005.

[43] The increases in glacial-earthquake activity in 1996 and 2000-2005 coincide with the observed retreat and acceleration of the glacier at those times. During the 200405 retreat and acceleration of Helheim, this glacier was the largest producer of glacial earthquakes in Greenland. The precipitous decrease in glacial-earthquake production at Helheim in 2006 corresponds with a period during which the lowest few $\mathrm{km}$ of the glacier appear to have thinned sufficiently to become ungrounded [Joughin et al., 2008a]. During 2006 calving at Helheim was observed [Joughin et al., 2008a] to be dominated by tabular icebergs $>1 \mathrm{~km}$ wide (similar to the tabular icebergs shown in Figure 9 (top)). Tabular icebergs do not capsize as they calve, and thus do not produce glacial earthquakes. During this time, GPS observations show a vertical tidal signal on the lower glacier [de Juan et al., 2010], indicating that a short section of the glacier was indeed floating. The lone glacial earthquake recorded at Helheim in 2006 occurred in late August, when the calving front was closest to the grounding line. The increased earthquake production in 2007 at Helheim coincides with a small retreat and regrounding of the glacier; the glacier was also grounded in summer of 2008 [de Juan et al., 2010], and the current authors' field observations suggest Helheim remained grounded in 2009 and 2010, consistent with ongoing glacial-earthquake activity in those years.

[44] As shown in Figure 3, changes in earthquake locations over time at Helheim are consistent with the pattern of calving-front changes described above. We note here that force directions for glacial earthquakes at Helheim, in addition to being generally consistent with the orientation of the calving front, also show a gradual clockwise rotation since the late 1990s. This rotation is consistent with changes in the calving-front geometry over the same time period, as observed from late-summer Landsat imagery, suggesting a very close link between glacier and earthquake characteristics. However, more detailed comparisons will be needed to validate and interpret this observation.

\subsubsection{Kangerdlugssuaq Glacier}

[45] Kangerdlugssuaq Glacier is the largest outlet glacier in East Greenland [Rignot and Kanagaratnam, 2006], and has produced a greater number of glacial earthquakes since 1993 than any other glacier. A close correspondence between large-scale calving events and glacial earthquakes at Kangerdlugssuaq during the summers of 2001-2006 was shown by Joughin et al. [2008a] and some characteristics of earthquake size and seasonality at this glacier were discussed by Tsai and Ekström [2007]. Kangerdlugssuaq Glacier has consistently generated multiple earthquakes every year since 1993 (Figure 8), for a total of 79 events and an average of 4.4 earthquakes/year. Locations of the earthquakes are shown in Figure 2. Variations in glacial-earthquake activity at Kangerdlugssuaq over the last 18 years are lower in amplitude than at the other glaciers discussed here, but we identify two periods of increased activity, one from 1995-1997, with 5.7 earthquakes/year, and another from 2003-2005, with 6.0 earthquakes/year. Three-year running averages otherwise range from 4.0-4.7 events/year in 1993-2002 and from 2.3-5.3 events/year in 2001-2010. Since 2005, Kangerdlugssuaq's annual rate of glacial-earthquake production has declined, to an average of 3.0 earthquakes/year during 2006-2010.

[46] Altimetry observations at Kangerdlugssuaq Glacier showed large thinning between repeat measurements made in 1993 and 1998 [Thomas et al., 2000]. Based on the low flow velocities they determined for 1995-96 and faster speeds in 1999, Thomas et al. [2000] concluded that the thinning began in or after 1995. Luckman et al. [2006] observed a 1-2 km advance of the calving front from 1992-1994, followed by a 2-3 km retreat in 1995-1997, at which time the glacier velocity also increased. By 2000, a pattern of seasonal advance and retreat of the calving front had established itself [Seale et al., 2011], but the mean position remained nearly constant until 2004. During 2004 2005 , the calving front retreated $\sim 5 \mathrm{~km}$ [Luckman et al., 2006; Seale et al., 2011]. The glacier flow speed also increased dramatically at this time [Luckman et al., 2006; Howat et al., 2007], and the lower reaches of the glacier thinned by $>100$ m compared with 2001 [Howat et al., 2007; Stearns and Hamilton, 2007]. From 2006 onward, the mean annual position of the Kangerdlugssuaq calving front has been steady, at a position slightly advanced from the 2005 minimum but several $\mathrm{km}$ behind the pre-retreat position. Seasonal variation in the front position is of similar amplitude to that observed in the early 2000s [Seale et al., 2011].

[47] Although the changes in earthquake numbers are small, the increase in glacial earthquakes in 1995-1997 corresponds in time to the thinning, small front retreat, and acceleration observed by Thomas et al. [2000] and Luckman et al. [2006] at that time. The 2003-2005 increase in glacialearthquake activity corresponds to the large-scale increases in velocity, thinning, and retreat observed then. The decrease in earthquakes in 2006-2010 compared with 2003-2005, returning the seismicity to levels slightly below that observed in the early 2000 s, corresponds to the restabilization of front behavior at Kangerdlugssuaq. We note also that the 1993-2010 earthquake data set shows the greatest frequency of earthquake occurrence at Kangerdlugssuaq in 
September-November, later than at other glaciers, as also observed by Tsai and Ekström [2007], but consistent with Kangerdlugssuaq's delayed seasonal retreat cycle [Joughin et al., 2008a; Nettles and Ekström, 2010; Seale et al., 2011]. 4.3.4. Jakobshavn Isbra

[48] Jakobshavn Isbræ is the largest outlet glacier in Greenland, and one of the best-studied glaciers in the world. Seismic signals of a variety of types have been studied at Jakobshavn by multiple authors [e.g., Ekström et al., 2003, 2006; Amundson et al., 2008, 2010; Tsai and Ekström, 2007; Rial et al., 2009; Walter et al., 2012]. Jakobshavn is one of the two field locations, together with Helheim Glacier, at which the correspondence of large-scale calving events and glacial earthquakes has been documented and the velocity response of the glacier demonstrated [Amundson et al., 2008; Nettles and Ekström, 2010; Walter et al., 2012]. We restrict our attention here to the long-period glacial earthquakes analyzed throughout this study.

[49] Jakobshavn has produced glacial earthquakes since 1998 (Figures 6 and 8), but production was sporadic prior to 2005. The first glacial earthquakes at Jakobshavn were observed during summer of 1998, when 6 events occurred. An additional 5 earthquakes occurred in summer of 1999. No further events occurred until 2005, when annual earthquake production commenced, with 1-2 earthquakes per year in 2005-2008, increasing to 6 and 4 events in 2009 and 2010 .

[50] Jakobshavn maintained a long, floating tongue for several decades prior to the mid-1990s, with relatively little inter-annual variation in the position of the ice front during that time [Sohn et al., 1998]. The glacier thickened slightly from 1991-1997, then began a period of rapid thinning, retreat, and acceleration [e.g., Thomas et al., 2003; Joughin et al., 2004, 2008b]. Tsai and Ekström [2007] noted the correspondence of the 1998-1999 period of earthquake activity with a $\sim 4 \mathrm{~km}$ retreat of Jakobshavn's tongue [Luckman and Murray, 2005], and the beginning of a multiyear period of acceleration [e.g., Joughin et al., 2004]. Joughin et al. [2008b] examined the correspondence between the 1998-99 events and glacier behavior in more detail, pointing out that the 1998 earthquakes, which occurred in June and July, correspond very closely in time to the initial dramatic speedup at Jakobshavn, constrained by Luckman and Murray [2005] to the period between satellite images taken in May and August, 1998. During June and July, the glacier retreated $\sim 2 \mathrm{~km}$ to what was then a record-minimum position. Joughin et al. [2008b] note that the calving front was at this time close to the 'rumples', rifts associated with a pinning point likely due to bedrock highs on the north [Thomas et al., 2003] and south [Echelmeyer et al., 1991] sides of the fjord. The 1999 earthquakes occurred during a period (April-August) without good satellite coverage, but sometime between April 1999 and February 2000 the glacier speed again increased significantly [Luckman and Murray, 2005], suggesting that these earthquakes occurred under a similar set of circumstances to the 1998 glacial earthquakes. During both the 1998 and 1999 earthquake sequences, the glacier appears to have been partially grounded at the north and south sides. In 2000, the calving front retreated past this pinning point [Joughin et al., 2004, 2008b; Luckman and Murray, 2005], and was again floating.
[51] The disintegration of most of the remaining floating tongue occurred by 2003 [Joughin et al., 2008b], at which time the glacier began a cycle of seasonal advance and retreat, with the minimum ice-front position typically reached in late August, and a short $(6-8 \mathrm{~km})$ floating tongue growing during the winter. Dietrich et al. [2007] observed vertical tidal motion close to the calving front in summer, 2004, with the calving front retreating behind their inferred grounding line in 2005. Earthquakes did not resume at Jakobshavn until 2005 (Figure 7), when the calving-front reached a new summer minimum position; summer calving fronts were then at or behind this position through 2010 [Joughin et al., 2008b; Seale et al., 2011; Truffer et al., 2011]. The glacier appears to have been grounded in summer since 2005 [Dietrich et al., 2007; Amundson et al., 2008, 2010].

[52] In 2005-2008, Jakobshavn averaged fewer than 2 earthquakes/year, with all events occurring during MayAugust, during the retreat phase of seasonal fluctuations in the calving-front position. In 2009, a marked increase to 6 earthquakes was seen, as the calving front again reached a record minimum position [e.g., Seale et al., 2011]. In 2010, for the first time, a glacial earthquake was recorded as early as February at Jakobshavn. This early onset of glacial earthquakes is consistent with the observation that, although the glacier began to grow a floating tongue in the early winter of 2009, this tongue was lost following the resumption of calving activity in December, 2009 [Truffer et al., 2011]. Retreat of the calving front to the grounding line thus occurred several months earlier than normal.

[53] One of the 2009 earthquakes bears special mention, having been studied in detail by Walter et al. [2012]. Two distinct calving events, and two corresponding earthquakes, occurred on August 21, 2009; we present results only for the first earthquake, which occurred at 07:02:18.8 (Table 1). The second earthquake is visible in inspection of the backprojected seismograms used for event detection, but presents a much weaker signal than the first. We find an azimuth of $299^{\circ}$ (or $119^{\circ}$, due to our $180^{\circ}$ ambiguity), plunge of $11^{\circ}$, and CSF amplitude of $4.4 \times 10^{13} \mathrm{~kg}-\mathrm{m} ;$ Walter et al. [2012] find corresponding values of $149^{\circ}\left(329^{\circ}\right), 12^{\circ}$, and $1.2 \times 10^{13} \mathrm{~kg}-\mathrm{m}$. The perpendicular to the calving front at the source location identified by Walter et al. [2012] was $\sim 303^{\circ}\left(123^{\circ}\right)$ prior to the calving events and $\sim 296^{\circ}\left(116^{\circ}\right)$ afterwards. We believe the two sets of seismological results to be in good agreement, particularly considering the different methodologies and data sets used for the two analyses.

[54] Finally, we note that Jakobshavn provides a clear example of glacial earthquakes that are missed by the 'standard' detection procedure used here to provide consistency across the 18-year data set, which relies on a particular baseline set of seismic networks. An additional four events were detected at Jakobshavn in 2010 by the near-real-time (NRT) version of the detector discussed in Section 2.1; these are clearly real earthquakes, not false detections, and waveform-modeling results for these events are included in Table 1, along with an additional lower-quality detection for 2009. The complexity of many events occurring at Jakobshavn (see also Walter et al. [2012]) may contribute to difficulty of detection, but there is clearly room for improvement in identification of these events on a global and regional scale. 


\subsubsection{Kong Oscar Glacier}

[55] Kong Oscar Glacier began producing glacial earthquakes in 2002. Since that time 30 glacial earthquakes have occurred at Kong Oscar, with a peak of 6 during 2004 (Figures 2 and 8). Glacial-earthquake production has been fairly steady at $\sim 3-4$ earthquakes/year since 2004, making Kong Oscar one of the most active producers of glacial earthquakes in recent years.

[56] The calving front of Kong Oscar Glacier retreated $\sim 1.5 \mathrm{~km}$ between 1992 and 2000 [Moon and Joughin, 2008], with an additional retreat of more than $3 \mathrm{~km}$ from 2000-2008 [Moon and Joughin, 2008; McFadden et al., 2011]. More than $1 \mathrm{~km}$ of this retreat occurred in 2002, with little change in 2003 and a return to retreat of several hundred meters per year in the following years [McFadden et al., 2011]. The glacier thinned by $4-28 \mathrm{~m} / \mathrm{yr}$ over this time [McFadden et al., 2011], and accelerated by a small amount in the interval 2000-2005 [Joughin et al., 2010]. A review of imagery obtained from the Landsat program shows a floating tongue prior to 2002. This tongue was heavily crevassed and fractured, lacking a distinct calving front and gradually becoming less and less consolidated as it progressed seaward, eventually separating into distinct tabular icebergs. These icebergs are readily identifiable in satellite imagery as large, intact blocks, whose surface maintains the textural characteristics of the intact glacier tongue (Figure 9, top), much like the tabular icebergs that calved from the floating terminus of Helheim Glacier in 2006 [Joughin et al., 2008a]. The ice tongue at Kong Oscar Glacier disintegrated completely during the period 20012002 , and the glacier had retreated to the mouth of its fjord by summer of 2003. From 2004 onwards, Kong Oscar shows a clearly delineated calving front, and the ice mélange is nearly devoid of large, upright icebergs, being dominated by smaller, overturned blocks and broken ice (Figure 9, bottom). These observations suggest a transition from a floating to a grounded or near-grounded terminus, with the transition beginning or occurring in 2002 .

[57] The onset of glacial-earthquake production at Kong Oscar Glacier in 2002 coincides with the transition from floating to grounded ice at the glacier terminus. The reason for the increase in glacial-earthquake production in 2004 is not obvious from the available data, but the calving front appears to be very close to the likely grounding line from this time onward. The steady rate of continued earthquake production since 2004 is consistent with the grounded style of calving we infer from the Landsat imagery. As discussed in Section 3, a few earthquakes at Kong Oscar Glacier show unusual force directions (Figure 2), and these events are obvious targets for more detailed future study.

\subsubsection{Alison Glacier}

[58] Alison Glacier lies at the southern end of Melville Bay. Over the last decade, Alison has nearly doubled its flow speed and has experienced one of the largest calving-front retreats in Greenland [Moon and Joughin, 2008; Joughin et al., 2008a, 2010; McFadden et al., 2011]. During this time, Alison Glacier produced 9 glacial earthquakes: the first 3 earthquakes were observed in 2003, 2005, and 2006, followed by 4 earthquakes in 2007 and 2 in 2008; no events were observed in 2009-2010.

[59] Little change in ice-front position occurred at Alison Glacier between 1992 and 2000 [Moon and Joughin, 2008].
The work of McFadden et al. [2011] shows that Alison retreated $\sim 2 \mathrm{~km}$ from 2000 to late 2002 , followed by $\sim 7 \mathrm{~km}$ of retreat from mid 2003 to early 2006 . An additional $\sim 1 \mathrm{~km}$ of ice was lost between late summer 2006 and the beginning of 2007. From 2007-2009, the front was relatively stable, retreating a total of $\sim 0.5 \mathrm{~km}$. The glacier flow speed increased fairly steadily from $2000-2005$, to a level $\sim 80 \%$ higher than in 2000 [McFadden et al., 2011]. The mean speed then appears to have leveled off, though with significant scatter possibly related to seasonal variability. We do not have good knowledge of the floatation level at Alison Glacier, but the elevation profiles of McFadden et al. [2011] show a transition from very low and flat ice near the calving front in 2002 and early 2003 to marginally higher-standing frontal ice in 2004-2005 and onwards. The front of the glacier stands particularly high in 2007, 90 m above sea level, suggesting the front is likely to have been grounded. Satellite imagery from 2007 also shows small, capsized icebergs in the fjord [Moon and Joughin, 2008, Figure 2]. By 2009, the ice surface had lowered by 20-30 m, and our inspection of Landsat imagery from summer 2009 shows an ice mélange dominated by tabular icebergs (similar to Figure 9, top), suggesting a floating front.

[60] The earthquakes in 2003-2005 occurred during the glacier's most rapid retreat phase, but it is difficult to assess the level of grounding of any part of the front during this time, especially since the mapped calving fronts [McFadden et al., 2011] suggest somewhat different behavior on the north and south sides of the glacier. The 2006 earthquake, in December, coincides with the late retreat of the glacier that year. Most of the earthquakes observed at Alison occurred in 2007, when the glacier front appears to have been grounded based on both iceberg character and elevation profiles. The cessation of earthquakes in 2009 appears to correspond to a return to floatation at the glacier front.

\subsubsection{Tracy Glacier}

[61] Tracy Glacier and its near neighbor Heilprin Glacier, which lies immediately to the south, terminate in Inglefield Bredning and together drain $\sim 10,000 \mathrm{~km}^{2}$ of the Northern Greenland Icesheet [Rignot and Kanagaratnam, 2006]. Although the termini of these glaciers are separated by only $15 \mathrm{~km}$, the geometry and location of the observed glacial earthquakes in this region suggest Tracy as the source. While not one of the most active producers of glacial earthquakes, Tracy Glacier is of interest due to its current position as the northernmost producer of glacial earthquakes, and the most recent glacier to become active in Northwest Greenland. Tracy began to produce glacial earthquakes in August of 2005 (Figure 8), and produced a single glacial earthquake annually through 2008 , since which time it has not produced an observed glacial earthquake.

[62] Tracy Glacier has been in recession for at least 90 years [Dawes and van As, 2010]. During much of this time it possessed a significant floating tongue, which extended beyond Tracy's fjord by several $\mathrm{km}$ and was also fed by additional glaciers to the north [Kollmeyer, 1980; Dawes and van As, 2010]. Based on observations made in 1968-1978, Kollmeyer [1980] describes calving at Tracy Glacier as producing "large flat icebergs", suggesting continued floatation. This mode of calving is seen as late as 2002, in a Landsat image captured in July of that year. By 2005, Landsat imagery shows that the calving front had retreated to the 
mouth of the fjord. In contrast to the large tabular bergs observed in July of 2002, a June, 2005, image shows the waters beyond the calving front filled with small, overturned blocks. This change in calving mode from stable, tabular icebergs to unstable, capsized icebergs suggests that Tracy was grounded or near grounded at this time. Between 2000 and 2005, flow speeds at Tracy Glacier increased by $40 \%$ [Rignot and Kanagaratnam, 2006; Joughin et al., 2010], and dynamic thinning was observed to elevations of at least $900 \mathrm{~m}$ [Pritchard et al., 2009].

[63] The change in calving style observed in 2005 and the inferred transition to a grounded or near-grounded calving front are consistent with the onset of glacial earthquakes in that year. The calving front remained at a similar position through at least 2009 [Dawes and van As, 2010], and earthquakes were produced in each year through 2008. The lack of earthquakes in 2009 and 2010 may indicate that the front of the glacier has thinned to floatation, as at Helheim in 2006 , or may reflect the statistics of small numbers of glacial earthquakes at this glacier. Further knowledge of the evolution of Tracy Glacier, and further assessment of the seismic record, will be needed to evaluate the causes of the recent apparent cessation of glacial earthquakes after 2008.

\subsubsection{Major Glaciers Not Producing Glacial Earthquakes}

[64] Using the combined catalog of Tsai and Ekström [2007] and this study, we have documented glacial earthquakes at more than 15 individual glaciers in Greenland. However, Moon and Joughin [2008] identified more than 200 outlet glaciers in Greenland with termini at least $2 \mathrm{~km}$ wide. Clearly, the majority of Greenland's outlet glaciers do not produce teleseismically observable glacial earthquakes. Many of these glaciers may simply not be thick enough to produce sufficiently massive icebergs to excite globally detectable seismic signals. As knowledge of bedrock topography increases across Greenland, we expect it will be possible to identify particular cases of geometrically similar glaciers that differ in earthquake productivity and to use these to improve our understanding of the conditions that are necessary for glacial earthquakes to occur. At some glaciers, glacial earthquakes may occur at sizes below our 'standard' detection threshold of $\mathrm{M}_{S W} \sim 4.6$, and regional observations will be required to identify these cases. At other glaciers, the lack of glacial-earthquake activity is unlikely to be an artifact of our detection threshold, but rather the result of differing dynamic conditions. We observe no glacial earthquakes at land-terminating glaciers like those that dominate in southwest Greenland, consistent with our interpretation that the earthquakes result from calving of large icebergs. We also do not observe glacial earthquakes at some of Greenland's largest outlet glaciers, including Petermann Glacier, Nioghalvfjerdsbræ (79 North), and Zachariae Isstrøm, despite significant losses of ice at these glaciers in recent years [e.g., Moon and Joughin, 2008]. All of these glaciers still terminate in long, floating ice tongues or ice shelves [Moon and Joughin, 2008; Thomas et al., 2009; Rignot and Steffen, 2008], and calve tabular icebergs far from the grounding line. The lack of glacial earthquakes at these large glaciers is thus also consistent with the collapsing-iceberg model of glacial-earthquake seismogenesis, and earthquakes are not expected to occur at these or similar glaciers unless the ice margin retreats to within a few $\mathrm{km}$ or less of the grounding line.

\section{Conclusions}

[65] We obtained estimates of centroid-single-force source parameters for 121 glacial earthquakes occurring in Greenland during 2006-2010, extending the time span for which such estimates are available to 18 years (1993-2010) and expanding the total number of available solutions by $65 \%$. These earthquakes include all of the events identified using the surface-wave detection approach of Ekström [2006], applied in a manner consistent with previous studies [Ekström et al., 2003, 2006; Tsai and Ekström, 2007; Nettles and Ekström, 2010], as well as several additional events identified using the same detection procedure and data from additional seismic stations. An error assessment using satellite-remote-sensing data finds a median centroid mislocation of $12 \mathrm{~km}$, with relative mislocation about half as large.

[66] All of the detected events are explained well by centroid-single-force (CSF) solutions. We find that the improved locations, force-direction estimates, and earthquake size distributions we retrieve are consistent with an explanation of the earthquake source process in which large, newly calved icebergs capsize against the calving front at marine-terminating outlet glaciers. We do not find any evidence for seismogenesis by basal sliding in this data set, suggesting that the seismic amplitudes of any such events occurring in Greenland are likely to be smaller than $\mathrm{M} \sim 4.5$, consistent with the small sizes of basal-sliding seismic events observed in Antarctica $\left(\mathrm{M}_{S}\right.$ 3.6-4.2) [Wiens et al., 2008].

[67] Spatiotemporal patterns of glacial-earthquake occurrence in Greenland correlate well with independently observed changes in glacier dynamics, both at the regional scale and at individual glaciers. Where data quality and quantity are sufficient, we observe that glacial-earthquake locations track the motion of the ice front over time. Earthquake occurrence tends to increase during periods of rapid glacier retreat, and correlates with periods of glacier thinning and acceleration. Detailed examination of the earthquakeoccurrence history at individual glaciers shows that earthquakes occur when the glacier calving front is at or very near the grounding line. This inference is also supported by the lack of glacial earthquakes at large glaciers draining into floating ice tongues or ice shelves, as in northern Greenland.

[68] At the regional scale, we document the northward propagation of earthquake occurrence in western Greenland over the observational period, with many previously inactive glaciers beginning to generate glacial earthquakes between 2000 and 2005. Most of these glaciers have remained seismically active since the onset of glacial-earthquake production. Earlier workers found little change in flow speed at glaciers in northwest Greenland between 2000 and 2005 [Rignot and Kanagaratnam, 2006]; more recent work has identified changes in flow speed, thinning rates, and calvingfront position during that time [Moon and Joughin, 2008; Joughin et al., 2010; Howat and Eddy, 2011; McFadden et al., 2011]. The onset of changes in ice-front position in the cases we have examined often precedes the onset of the 
glacial earthquakes, both seasonally and interannually; in some cases, the onset of glacier thinning and acceleration also precede the onset of earthquake occurrence. Rignot and Kanagaratnam [2006] noted that, although they did not find significant dynamic changes in the northwest Greenland glaciers, the mass balance for these glaciers was generally negative, and suggested that any related changes in ice dynamics must have occurred decades earlier. The correspondence between glacial-earthquake occurrence and the calving of grounded ice leads us to suggest that, indeed, an important change in ice dynamics took place in northwest Greenland in the early 2000s, with many glaciers transitioning from floating to grounded termini.

[69] Although much remains to be learned about the glacial-earthquake source process, analysis of these events provides information about glacier behavior and dynamics complementary to that obtained from other forms of remote sensing, including providing an additional means to assess the grounding state of the calving front. It is clear that patterns of glacial-earthquake occurrence respond to both local and regional-scale forcings, and further study combining seismological and glaciological observations will help to clarify additional controls on the generation of glacial earthquakes, providing both better tools for investigation of glacier dynamics and better explanations of a little-explored part of the seismic wavefield.

[70] Acknowledgments. The GSN data analyzed in this study were collected and distributed by the Incorporated Research Institutions for Seismology (IRIS), the USGS, the CNSN, and the Geoscope, Geofon and Mednet projects; additional data were provided by the GLISN project and the Lamont Cooperative Seismographic Network. We thank I. Joughin for providing calving-front locations for Helheim and Kangerdlugssuaq Glaciers in digital form. We appreciate constructive comments from associate editor M. Truffer and reviewers D. Wiens, F. Walter, and J. Amundson, which improved the manuscript. This research was supported by NSF grants ARC-07-13970 and EAR-09-44055.

\section{References}

Abdalati, W., W. Krabill, E. Frederick, S. Manizade, C. Martin, J. Sonntag, R. Swift, R. Thomas, W. Wright, and J. Yungel (2001), Outlet glacier and margin elevation changes: Near-coastal thinning of the Greenland ice sheet, J. Geophys. Res., 106(D24), 33,729-33,741, doi:10.1029/ 2001JD900192.

Amundson, J. M., M. Truffer, M. P. Lüthi, M. Fahnestock, M. West, and R. J. Motyka (2008), Glacier, fjord, and seismic response to recent large calving events, Jakobshavn Isbræ, Greenland, Geophys. Res. Lett., 35, L22501, doi:10.1029/2008GL035281.

Amundson, J. M., M. Fahnestock, M. Truffer, J. Brown, M. P. Lüthi, and R. J. Motyka (2010), Ice mélange dynamics and implications for terminus stability, Jakobshavn Isbræ, Greenland, J. Geophys. Res., 115, F01005, doi:10.1029/2009JF001405.

Amundson, J. M., J. C. Burton, and S. Correa-Legisos (2012), Impact of hydrodynamics on seismic signals generated by iceberg collisions, Ann. Glaciol., 53(60), 106-112, doi:10.3189/2012/AoG60A012.

Andresen, C. S., et al. (2012), Rapid response of Helheim Glacier in Greenland to climate variability over the past century, Nat. Geosci., 5(1), 37-41, doi:10.1038/ngeo1349.

Burton, J. C., et al. (2012), Laboratory investigations of iceberg capsize dynamics, energy dissipation and tsunamigenesis, J. Geophys. Res., 117, F01007, doi:10.1029/2011JF002055

Chen, X., P. M. Shearer, F. Walter, and H. A. Fricker (2011), Seventeen Antarctic seismic events detected by global surface waves and a possible link to calving events from satellite images, J. Geophys. Res., 116, B06311, doi:10.1029/2011JB008262.

Dawes, P. R., and D. van As (2010), An advancing glacier in a recessive ice regime: Berlingske Bræ, North-West Greenland, Geol. Soc. Den. Greenl. Bull., 20, 79-82.

de Juan, J., et al. (2010), Sudden increase in tidal response linked to calving and acceleration at a large Greenland outlet glacier, Geophys. Res. Lett. 37, L12501, doi:10.1029/2010GL043289.
Dietrich, R., H.-G. Maas, M. Baessler, A. Rülke, A. Richter, E. Schwalbe, and P. Westfeld (2007), Jakobshavn Isbræ, West Greenland: Flow velocities and tidal interaction of the front area from 2004 field observations, J. Geophys. Res., 112, F03S21, doi:10.1029/2006JF000601.

Dziewonski, A. M., and D. L. Anderson (1981), Preliminary reference Earth model, Phys. Earth Planet. Inter., 25, 297-356.

Dziewonski, A. M., T.-A. Chou, and J. H. Woodhouse (1981), Determination of earthquake source parameters from waveform data for studies of global and regional seismicity, J. Geophys. Res., 86(B4), 2825-2852, doi:10.1029/JB086iB04p02825.

Echelmeyer, K., T. S. Clarke, and W. D. Harrison (1991), Surficial glaciology of Jakobshavn Isbræ, West Greenland: Part I. Surface morphology, J. Glaciol., 37(127), 368-382.

Ekström, G. (2006), Global detection and location of seismic sources by using surface waves, Bull. Seismol. Soc. Am., 96(4A), 1201-1212.

Ekström, G., M. Nettles, and G. A. Abers (2003), Glacial earthquakes, Science, 302, 622-624.

Ekström, G., A. M. Dziewonski, N. N. Maternovskaya, and M. Nettles (2005), Global seismicity of 2003: Centroid-moment-tensor solutions for 1087 earthquakes, Phys. Earth Planet. Inter., 148, 327-351.

Ekström, G., M. Nettles, and V. C. Tsai (2006), Seasonality and increasing frequency of Greenland glacial earthquakes, Science, 311, 1756-1758.

Ekström, G., M. Nettles, and A. M. Dziewoński (2012), The global CMT project 2004-2010: Centroid-moment tensors for 13,017 earthquakes, Phys. Earth Planet. Inter., 200-201, 1-9, doi:10.1016/j.pepi.2012.04.002. Gutenberg, B., and C. F. Richter (1944), Frequency of earthquakes in California, Bull. Seismol. Soc. Am., 34, 185-188.

Hamilton, G. S., et al. (2008), Iceberg calving and flow dynamics at Helheim Glacier, East Greenland, from time-lapse photography, Eos Trans. $A G U, 89(53)$, Fall Meet. Suppl., Abstract C13A-0565.

Holland, D. M., R. H. Thomas, B. DeYoung, M. H. Ribergaard, and B. Lyberth (2008), Acceleration of Jakobshavn Isbræ triggered by warm subsurface ocean waters, Nat. Geosci., 1(10), 659-664, doi:10.1038/ ngeo316.

Howat, I. M., and A. Eddy (2011), Multi-decadal retreat of Greenland's marine-terminating glaciers, J. Glaciol., 57(203), 389-396, doi:10.3189/ 002214311796905631 .

Howat, I. M., I. Joughin, S. Tulaczyk, and S. Gogineni (2005), Rapid retreat and acceleration of Helheim Glacier, east Greenland, Geophys. Res. Lett., 32, L22502, doi:10.1029/2005GL024737.

Howat, I. M., I. Joughin, and T. A. Scambos (2007), Rapid changes in ice discharge from Greenland outlet glaciers, Science, 315, 1559-1561, doi:10.1126/science. 1138478 .

Howat, I. M., I. Joughin, M. Fahnestock, B. E. Smith, and T. A. Scambos (2008), Synchronous retreat and acceleration of southeast Greenland outlet glaciers 2000-06: Ice dynamics and coupling to climate, J. Glaciol. 54(187), 646-660.

Jiang, Y., T. H. Dixon, and S. Wdowinski (2010), Accelerating uplift in the North Atlantic region as an indicator of ice loss, Nat. Geosci., 3(6), 404-407, doi:10.1038/ngeo845.

Joughin, I., W. Abdalati, and M. Fahnestock (2004), Large fluctuations in speed on Greenland's Jakobshavn Isbræ glacier, Nature, 432, 608-610.

Joughin, I., I. Howat, R. B. Alley, G. Ekström, M. Fahnestock, T. Moon, M. Nettles, M. Truffer, and V. C. Tsai (2008a), Ice-front variation and tidewater behavior on Helheim and Kangerdlugssuaq Glaciers, Greenland, J. Geophys. Res., 113, F01004, doi:10.1029/2007JF000837.

Joughin, I., I. M. Howat, M. Fahnestock, B. Smith, W. Krabill, R. B. Alley, H. Stern, and M. Truffer (2008b), Continued evolution of Jakobshavn Isbrae following its rapid speedup, J. Geophys. Res., 113, F04006, doi:10.1029/2008JF001023

Joughin, I., B. E. Smith, I. M. Howat, T. Scambos, and T. Moon (2010), Greenland flow variability from ice-sheet-wide velocity mapping, J. Glaciol, 56(197), 415-430.

Kawakatsu, H. (1989), Centroid single force inversion of seismic waves generated by landslides, J. Geophys. Res., 94, 12,363-12,374.

Khan, S. A., J. Wahr, M. Bevis, I. Velicogna, and E. Kendrick (2010) Spread of ice mass loss into Northwest Greenland observed by GRACE and GPS, Geophys. Res. Lett., 37, L06501, doi:10.1029/2010GL042460.

Kollmeyer, R. C. (1980), West Greenland outlet glaciers: An inventory of the major iceberg producers, Cold Reg. Sci. Technol., 1, 175-181.

Krabill, W., E. Frederick, S. Manizade, C. Martin, J. Sonntag, R. Swift, R. Thomas, W. Wright, and J. Yungel (1999), Rapid thinning of parts of the southern Greenland ice sheet, Science, 283(5407), 1522-1524, doi:10.1126/science.283.5407.1522.

Krabill, W., et al. (2004), Greenland ice sheet: Increased coastal thinning, Geophys. Res. Lett., 31, L24402, doi:10.1029/2004GL021533.

Luckman, A., and T. Murray (2005), Seasonal variation in velocity before retreat of Jakobshavn Isbræ, Greenland, Geophys. Res. Lett., 32 , L08501, doi:10.1029/2005GL022519. 
Luckman, A., T. Murray, R. de Lange, and E. Hanna (2006), Rapid and synchronous ice-dynamic changes in East Greenland, Geophys. Res. Lett., 33, L03503, doi:10.1029/2005GL025428.

Luthcke, S. B., H. J. Zwally, W. Abdalati, D. D. Rowlands, R. D. Ray, R. S. Nerem, F. G. Lemoine, J. J. McCarthy, and D. S. Chinn (2006), Recent Greenland ice mass loss by drainage system from satellite gravity observations, Science, 314, 1286-1289, doi:10.1126/science.1130776.

MacAyeal, D. R., T. A. Scambos, C. L. Hulbe, and M. A. Fahnestock (2003), Catastrophic ice-shelf break-up by an ice-shelf-fragment-capsize mechanism, J. Glaciol., 49(164), 22-36.

McFadden, E. M., I. M. Howat, I. Joughin, B. E. Smith, and Y. Ahn (2011), Changes in the dynamics of marine terminating outlet glaciers in west Greenland (2000-2009), J. Geophys. Res., 116, F02022, doi:10.1029/ $2010 J F 001757$.

Moon, T., and I. Joughin (2008), Changes in ice front position on Greenland's outlet glaciers from 1992 to 2007, J. Geophys. Res., 113, F02022, doi:10.1029/2007JF000927.

Murray, T., et al. (2010), Ocean regulation hypothesis for glacier dynamics in southeast Greenland and implications for ice sheet mass changes, J. Geophys. Res., 115, F03026, doi:10.1029/2009JF001522.

Nettles, M., and G. Ekström (2010), Glacial earthquakes in Greenland and Antarctica, Ann. Rev. Earth Planet. Sci., 38, 467-491, doi:10.1146/ annurev-earth-040809-152414.

Nettles, M., et al. (2008a), Step-wise changes in glacier flow speed coincide with calving and glacial earthquakes at Helheim Glacier, Greenland, Geophys. Res. Lett., 35, L24503, doi:10.1029/2008GL036127.

Nettles, M., et al. (2008b), Glacier acceleration, glacial earthquakes, and ice loss at Helheim Glacier, Greenland, EOS Trans. $A G U, 89(52)$, Fall Meet. Suppl., Abstract G23A-02.

Pritchard, H. D., R. J. Arthern, D. G. Vaughan, and L. A. Edwards (2009), Extensive dynamic thinning on the margins of the Greenland and Antarctic ice sheets, Nature, 461(7266), 971-975, doi:10.1038/nature08471.

Rial, J. A., C. Tang, and K. Steffen (2009), Glacial rumblings from Jakobshavn ice stream, Greenland, J. Glaciol., 55(191), 389-399.

Rignot, E., and P. Kanagaratnam (2006), Changes in the velocity structure of the Greenland Ice Sheet, Science, 311, 986-990, doi:10.1126/ science. 1121381.

Rignot, E., and K. Steffen (2008), Channelized bottom melting and stability of floating ice shelves, Geophys. Res. Lett., 35, L02503, doi:10.1029/ 2007GL031765.

Rignot, E., J. E. Box, E. Burgess, and E. Hanna (2008), Mass balance of the Greenland ice sheet from 1958 to 2007, Geophys. Res. Lett., 35, L20502, doi:10.1029/2008GL035417.

Seale, A., P. Christoffersen, R. I. Mugford, and M. O'Leary (2011), Ocean forcing of the Greenland ice sheet: Calving fronts and patterns of retrea identified by automatic satellite monitoring of eastern outlet glaciers, J. Geophys. Res., 116, F03013, doi:10.1029/2010JF001847.
Smith, G. P., and G. Ekström (1997), Interpretation of earthquake epicenter and CMT centroid locations, in terms of rupture length and direction, Phys. Earth Planet. Inter., 102(1-2), 123-132.

Sohn, H.-G., K. C. Jezek, and C. J. van der Veen (1998), Jakobshavn Glacier, west Greenland: 30 years of spaceborne observations, Geophys. Res. Lett., 25(14), 2699-2702, doi:10.1029/98GL01973.

Stearns, L. A., and G. S. Hamilton (2007), Rapid volume loss from two East Greenland outlet glaciers quantified using repeat stereo satellite imagery, Geophys. Res. Lett., 34, L05503, doi:10.1029/2006GL028982.

Straneo, F., G. S. Hamilton, D. A. Sutherland, L. A. Stearns, F. Davidson, M. O. Hammill, G. B. Stenson, and A. Rosing-Asvid (2010), Rapid circulation of warm subtropical waters in a major glacial fjord in East Greenland, Nat. Geosci., 3(3), 182-186, doi:10.1038/ngeo764.

Thomas, R. H., W. Abdalati, T. L. Akins, B. M. Csatho, E. B. Frederick, S. P. Gogineni, W. B. Krabill, S. S. Manizade, and E. J. Rignot (2000), Substantial thinning of a major East Greenland outlet glacier, Geophys. Res. Lett., 27(9), 1291-1294, doi:10.1029/1999GL008473.

Thomas, R. H., W. Abdalati, E. Frederick, W. B. Krabill, S. Manizade, and K. Steffen (2003), Investigation of surface melting and dynamic thinning on Jakobshavn Isbræ, Greenland, J. Glaciol., 49(165), 231-239.

Thomas, R. H., E. Frederick, W. Krabill, S. Manizade, and C. Martin (2009) Recent changes on Greenland outlet glaciers, J. Glaciol., 55(189), 147-162, doi:10.3189/002214309788608958.

Truffer, M., J. Amundson, M. Fahnestock, I. Joughin, and R. Motyka (2011), Ocean regulation of ice flow, paper presented at International Symposium on Interactions of Ice Sheets and Glaciers With the Ocean, Int. Glaciol. Soc., La Jolla, Calif., 6-10 June.

Tsai, V. C., and G. Ekström (2007), Analysis of glacial earthquakes, J. Geophys. Res., 112, F03S22, doi:10.1029/2006JF000596.

Tsai, V. C., J. R. Rice, and M. Fahnestock (2008), Possible mechanisms for glacial earthquakes, J. Geophys. Res., 113, F03014, doi:10.1029/ 2007JF000944.

van den Broeke, M., J. Bamber, J. Ettema, E. Rignot, E. Schrama, W. J. van de Berg, E. van Meijgaard, I. Velicogna, and B. Wouters (2009), Partitioning recent Greenland mass loss, Science, 326(5955), 984-986, doi: $10.1126 /$ science. 1178176

Velicogna, I., and J. Wahr (2005), Greenland mass balance from GRACE, Geophys. Res. Lett., 32, L18505, doi:10.1029/2005GL023955.

Walter, F., J. M. Amundson, S. O’Neel, M. Truffer, M. Fahnestock, and H. A. Fricker (2012), Analysis of low-frequency seismic signals generated during a multiple-iceberg calving event at Jakobshavn Isbræ, Greenland, J. Geophys. Res., 117, F01036, doi:10.1029/2011JF002132.

Wiens, D. A., S. Anandakrishnan, J. P. Winberry, and M. A. King (2008), Simultaneous teleseismic and geodetic observations of the stick-slip motion of an Antarctic ice stream, Nature, 453(7196), 770-774, doi:10.1038/ nature06990.

Wouters, B., D. Chambers, and E. J. O. Schrama (2008), GRACE observes small-scale mass loss in Greenland, Geophys. Res. Lett., 35, L20501, doi:10.1029/2008GL034816. 